\title{
OMICS PLATFORM TECHNOLOGIES FOR DISCOVERY AND UNDERSTANDING THE SYSTEMS BIOLOGY OF OIL PALM
}

\author{
UMI SALAMAH RAMLI*; ABRIZAH OTHMAN*; BENJAMIN LAU YII CHUNG*; HASLIZA HASSAN*; \\ NUR 'AIN MOHD ISHAK; ZAIN NURAZAH*; NURUL LIYANA ROZALI*; NOOR IDAYU MHD TAHIR*; \\ SYAHANIM SHAHWAN*; SHAHIRAH BALQIS DZULKAFLI*; RAJINDER SINGH*; OMAR ABD RASID*; \\ RAVIGADEVI SAMBANTHAMURTHI*; MOHAMAD ARIF ABD MANAF* and GHULAM KADIR AHMAD \\ PARVEEZ*
}

\begin{abstract}
Palm oil is the leading vegetable oil in terms of volume in the world market. Indonesia and Malaysia are the top producers and exporters of the commodity. The global production of palm oil reached 73.5 million tonnes in the period 2018/2019, up from approximately 70.5 million tonnes in 2017/2018. Oil palm is the most productive crop in the world being 10 times more productive than soyabean which produces only about 0.45 toil per hectare. Nonetheless, the industry is continuously under pressure to improve productivity and sustainability. This will require concerted innovations across the entire palm oil supply chain and fully committed research efforts including upstream technologies to expedite crop improvement. At the Malaysian Palm Oil Board (MPOB), research efforts at development of tools for improving oil palm traits by genetic modification have been augmented more recently with omics-based approaches and all of these innovations are synchronised towards improved product quality. Omics is a multi-disciplinary field encompassing genomics, epigenomics, transcriptomics, proteomics and metabolomics. Each of these fields provides an opportunity to understand and view oil palm biology from a global perspective, enabling accelerated discoveries for improved productivity and the development of new and improved varieties. An integrative omics approach promises great value in both phenotyping and diagnostic analyses. With the current technological capabilities, metabolomics is also being exploited for identifying unique chemical fingerprints to detect product contamination and adulteration in oil palm. This effort is actively being conducted in order to position the oil palm industry to meet and optimise the delivery of the highest quality oil with minimum environmental and social concerns. In this review, an overview is given on the current knowledge and progress made in oil palm research, focusing on the application of omics strategies and their integration with high-throughput technologies for oil palm crop improvement, development of geographical traceability system and ensuring that palm oil is free from residual oil contamination.
\end{abstract}

Keywords: omics research, proteomics, metabolomics, traceability, crop improvement.

Received: 17 March 2020; Accepted: 21 July 2020; Published online: 7 October 2020.

\section{INTRODUCTION}

Palm oil (from Elaeis guineensis Jacq.) is one of the most highly valued commodities for Malaysia and

\footnotetext{
Malaysian Palm Oil Board,

6 Persiaran Institusi, Bandar Baru Bangi,

43000 Kajang, Selangor, Malaysia.

E-mail: umi@mpob.gov.my
}

contributes significantly to the economic growth of the country (Kushairi et al., 2019). In terms of yield, the oil palm is characterised as the most productive oil crop with a potential yield capacity of more than $10 \mathrm{t}$ of oil per hectare per year (Murphy, 2014). However, generally, yield gaps in oil palm plantation are large, with yields typically between 4-6 t of oil per hectare for the best commercial plantations and 
3-4 $t$ oil per hectare for smallholders. Assessment of the underlying causes of yield gaps in oil palm production systems worldwide is still lacking (Woittiez et al., 2017). Palm oil is used worldwide and contributes significantly to the world's oils and fats market (Nambiappan et al., 2018; Parveez et al., 2020). There are many factors that contribute to the global demand for palm oil. These include increasing awareness of its health attributes, competitive price and versatility that allows it to be used in both food and non-food applications (May and Nesaretnam, 2014; Khosla, 2011). Malaysia is the second largest producer of palm oil in the world behind Indonesia. The overall production in Malaysia in 2019 was over 19.86 million tonnes of crude palm oil from 5.9 million hectares of planted area. India and China are the two largest palm oil export destination, with the European Union (EU) also being among the main markets for Malaysia's key commodity. In 2019, Malaysia exported a total of 16.88 million tonnes of palm oil to the world indicating a strong demand from importing countries, especially India, China and the EU as compared to 15.36 million tonnes in the previous year (Parveez et al., 2020).

Unstable commodity prices, labour shortage, ageing oil palm populations, and pests and diseases that seriously affect overall yield are among the key challenges faced by the oil palm industry (Alam et al., 2015; Murphy, 2014). A viable solution for overcoming these challenges is through the development of varieties that can increase yield per unit land, are more resilient even to climate change and produce diversified and more high value products (Murphy, 2014). Oil palm breeding programmes focussed on specific traits such as high yield, water uptake efficiency, nutrient use efficiency, disease resistance and plant architecture will be essential in the future for improving commercial yields. While conventional breeding has its limitations, application of biotechnological tools will be a viable strategy for overcoming the above challenges. Fortunately, tools are available to assist crop improvement such as genetic modification for producing high value products and developing oil palm with pest and disease tolerance. This is to keep pace with global population growth and meet the increasing demand for palm oil for both food and non-food applications (Parveez et al., 2015).

Tremendous progress has been made in recent years in the area of modern genetics through integration with other omics technologies (Teh et al., 2017). Biochemical and genetic studies have revealed that in many crops including oil palm, the majority of important agronomic traits such as yield, plant height and nutrient content are complex quantitative traits that are controlled by multiple interacting genes (Seng et al., 2016; Long et al., 2007; Ramli et al., 2002a, b). To understand the inheritance of complex traits, the establishment of reliable screening tools and platforms that can precisely measure expression of physiological traits in realistic field environments is important. The emergence of the novel omics innovations, for example, genomics, proteomics and metabolomics has allowed scientists to identify the molecular mechanisms underpinning crop improvement (Tester and Langridge, 2010; Syrenne et al., 2012; Appleton et al., 2014; Chaudhary et al., 2015). In this respect, genomics and epigenomics-based technologies have successfully provided the necessary tools that will support the sustainable development of oil palm (Low et al., 2017; Ong-Abdullah et al., 2015; Singh et al., 2013a, b; 2020). Concomitantly, remarkable progress in omics research, combining innovative and accurate technologies with the requirement for intersection with bioinformatics has resulted in the discovery of key regulators of various traits for crop improvement (Hajduch et al., 2011; Chaudhary et al., 2015; Fernie and Schauer, 2009).

The use of proteomics and metabolomics in oil palm research was initiated about 10 years ago, aimed at developing tools to accurately monitor the proteome and metabolome profiles of clonal/ transgenic palms and for a variety of important biological traits, e.g. yield, oil quality and disease resistance (Ramli et al., 2016). Several technical and review reports are available on appropriate strategies for the application of molecular characterisation using proteomics and metabolomics in oil palm to improve our understanding of these complex traits, which are likely to underpin future gains in crop productivity (Teh et al., 2017; Dzulkafli et al., 2019; Hassan et al., 2019; Lau et al., 2018; Rozali et al., 2017; Nurazah et al., 2017; Vargas et al., 2014; Neoh et al., 2013; Tahir et al., 2016; 2012). Recent developments in high-throughput omics technologies have also accelerated the accumulation of huge amounts of omics data from multiple sources - genome, epigenome, transcriptome, proteome and metabolome, posing new challenges and opportunities for developing novel computational approaches customised for integrative analysis (Mirza et al., 2019). Consequently, simultaneous analysis of data obtained from different omics platforms, for the same biological specimen is expected to provide a holistic view of the complex biological interactions. The use of state-of-the-art machine learning (ML)-based approaches, which leverage prior knowledge of biological networks to integrate omics-datasets would be vital for robust biomarker modelling (Mirza et al., 2019; Tafti et al., 2017; Glaab, 2016; Price et al., 2017). Thus, the various omics information is not just only assisting in the establishment of deeper understanding of the complex interactions of oil palm metabolic networks and their responses to environmental and genetic changes, but also providing screening and analysis platforms to support oil palm breeding programmes. 
Such information will have major implications in enhancing the future production and sustainability of the oil palm industry.

\section{TRANSLATING GENOMICS RESEARCH TO IMPROVE OIL PALM PRODUCTIVITY}

Early application of genomics-based tools in oil palm breeding was initiated in the mid-1990s, where restriction fragment length polymorphism (RFLP) markers were employed for DNA fingerprinting (Cheah et al., 1993; Mayes et al., 1996). This was followed by the use of RFLP markers for the construction of a framework genetic map (Mayes et al., 1997). Subsequent development of polymerase chain reaction (PCR)-based simple sequence repeat (SSR) markers led to the construction of a denser oil palm genetic map (Billotte et al., 2005) and made available a more robust tool for fingerprinting (Singh et al., 2008; Ting et al., 2010). Systematic study of genes in oil palm via generation of expressed sequence tags (EST) (Jouannic et al., 2005; Ho et al., 2007; Low et al., 2008; Chan et al., 2010) was an important first step in building the sequence database for oil palm, which was followed by sequencing of the hypomethylated regions of the genome (Low et al., 2014).

A high quality genetic blueprint of both species of oil palm, namely E. guineensis and E. oleifera, was eventually obtained using a combination of $454 /$ Roche technology and bacterial artificial chromosome (BAC) end sequencing in 2013 (Singh et al., 2013a). Scaffolds from the build were successfully aligned to the 16 linkage groups of the oil palm genetic map, and sequencing of 34 transcriptomes from various tissues enhanced the annotation of the assembly. The importance of the availability of this resource was quickly realised as it proved pivotal in identifying the Shell and Virescens genes responsible for the three different fruit forms and the exocarp colour of oil palm fruits (two important monogenic traits), respectively (Singh et al., 2014; $2013 b)$. The identification of these genes paved the way for the realisation of genomics guided breeding in oil palm, which was previously restricted to using molecular markers for deoxyribonucleic acid (DNA) fingerprinting and paternity testing of selected oil palm breeding lines and tissue culture clones (Thongthawee et al., 2010; Singh et al., 2007). Moving forward, and building on the experience of other crops, further refinements to the first oil palm genome assembly are necessary, especially to facilitate the identification of genes regulating complex (quantitative) traits.

Nevertheless, the availability of the pisifera E. guineensis genome sequence has facilitated the assembly of the dura E. guineensis genome apart from the resequencing of 17 other mostly advanced breeding lines (Jin et al., 2016). The dura genome as expected appeared to be similar to the pisifera genome in terms of the percentage of repeat sequences present $(\sim 40 \%)$, and the number of genes identified, 36105 , which was close to the number reported by Singh et al. (2013a). More importantly, the re-sequencing of the 17 palms revealed that the genetic diversity of palms in South-east Asia is rather low, consistent with earlier studies using molecular markers (Maizura et al., 2006), which also suggested that the genetic variability of palms used for commercial cultivation in this region is low. The availability of the genome sequence had facilitated the resequencing of another 132 palms from both species and development of a high density single nucleotide polymorphism (SNP) array, consisting of 200000 probes (Kwong et al., 2016). The 200000 single nucleotide polymorphisms were selected across the genome and thus, proved useful in a Genome Wide Association Study (GWAS) that led to the identification of loci influencing oil content in selected E. guineensis backgrounds (Teh et al., 2016). A clear advantage of a fixed high density SNP array platform is that it can provide a rapid scan of the genome, with high SNP call rates and as the number of samples being genotyped increases, cost per sample gets lower (Thomson, 2014). In addition, use of a fixed array allows for a more robust comparison of fingerprints across multiple populations or accessions. However, one of the main disadvantages of the fixed array platform is that the single nucleotide polymorphisms are restricted to those found in the samples or accession used to design the array and in the case of oil palm, existing SNP platforms may not be incorporating rare single nucleotide polymorphisms found in wild germplasm samples. This can be a critical issue for oil palm breeding in South-east Asia, where the limited diversity requires the industry to introgress desirable alleles from wild oil palm collections into advanced breeding lines (Ong-Abdullah et al., 2015; Zulkifli et al., 2012; Singh et al., 2008).

Developments in next generation sequencing (NGS) technologies paved the way for an alternative genotyping technique known as genotype by sequencing (GBS) (Nielsen et al., 2011). GBS which entails low coverage skim sequencing of samples, reduces cost substantially, but nevertheless, requires a fairly good existing genome build to anchor the sequences and accurately call the SNP. The availability of the high quality oil palm genome build facilitated GBS studies in oil palm, where Pootakham et al. (2015), after further reducing the complexity by digesting the DNA samples with restriction enzymes, skim sequenced 108 palms from a mapping family. More than 20000 high quality SNP were detected by mapping the GBS reads to the oil palm reference genome, which led to the construction of a genetic map, and more importantly, identification of genomic loci associated with key agronomic traits, 
namely height increment and bunch weight. Using a similar GBS approach, again with the published oil palm genome sequence as reference, Bai et al. (2017) skim sequenced 155 palms (inclusive of both parental palms) of a $F_{1}$ family, and identified single nucleotide polymorphisms linked to oil content. The studies above clearly indicate how the availability of the genome build since 2013 has facilitated the application of the most current genomics-based technologies for marker-trait association in oil palm. Interestingly, the growing repertoire of sequences available for oil palm and research advancements in model crop systems, further facilitates the use of the candidate gene approach to uncover the molecular mechanisms influencing particular traits of interest. Exploiting this, Ong et al. (2018) designed SNP markers from selected candidate genes and in combination with the association mapping approach, identified a SNP marker linked to stem height in the MPOB-Angola germplasm collection revealing an alternative but more focussed route to establish marker-trait association.

Undeniably, the genomic resources established thus far are an important foundation, that will help improve oil palm breeding efficiency (Figure 1). However, to capture the full complexity of a biological system like oil palm, a combined 'omics' approach is required to uncover complex traits such as disease resistance and adaption to abiotic stresses (e.g. drought tolerance). Genomics efforts are in full gear currently for the oil palm and integrating with recent developments in proteomics (Lau et al., 2018) and metabolomics (Ramli et al., 2016; Rodrigues-Neto et al., 2018) will prove important to fully understand the regulatory systems that govern complex traits. However, rapid developments in each of the 'omics' platforms is resulting in vast amounts of complex data that require high end computational analysis by competent researchers to make incisive interpretations from such multi-omics datasets (Misra et al., 2019).

\section{PROTEOMICS AND METABOLOMICS - CURRENT AND EMERGING METHODOLOGIES IN CROP IMPROVEMENT}

The essential functions of living cells, e.g. during cell differentiation and regulation or during disease development, are accomplished by gene products, mainly proteins. Thus, it is important to study the proteins involved in order to gain clues about their functional activity. In fact, proteomics is a tool for functional genomics and holds special promise for genetics and physiological studies towards crop improvement (Eldakak et al., 2013; Fiehn et al., 2001). Therefore, technologies aimed at studying proteins in a cell are a welcome complement to uncover the role of genes in cellular activities. Since proteins are involved in cellular enzymatic functions, regulatory switches and structural components, characterising the proteins expressed by a cell can give important clues to the function, organisation and responsiveness of a cell.

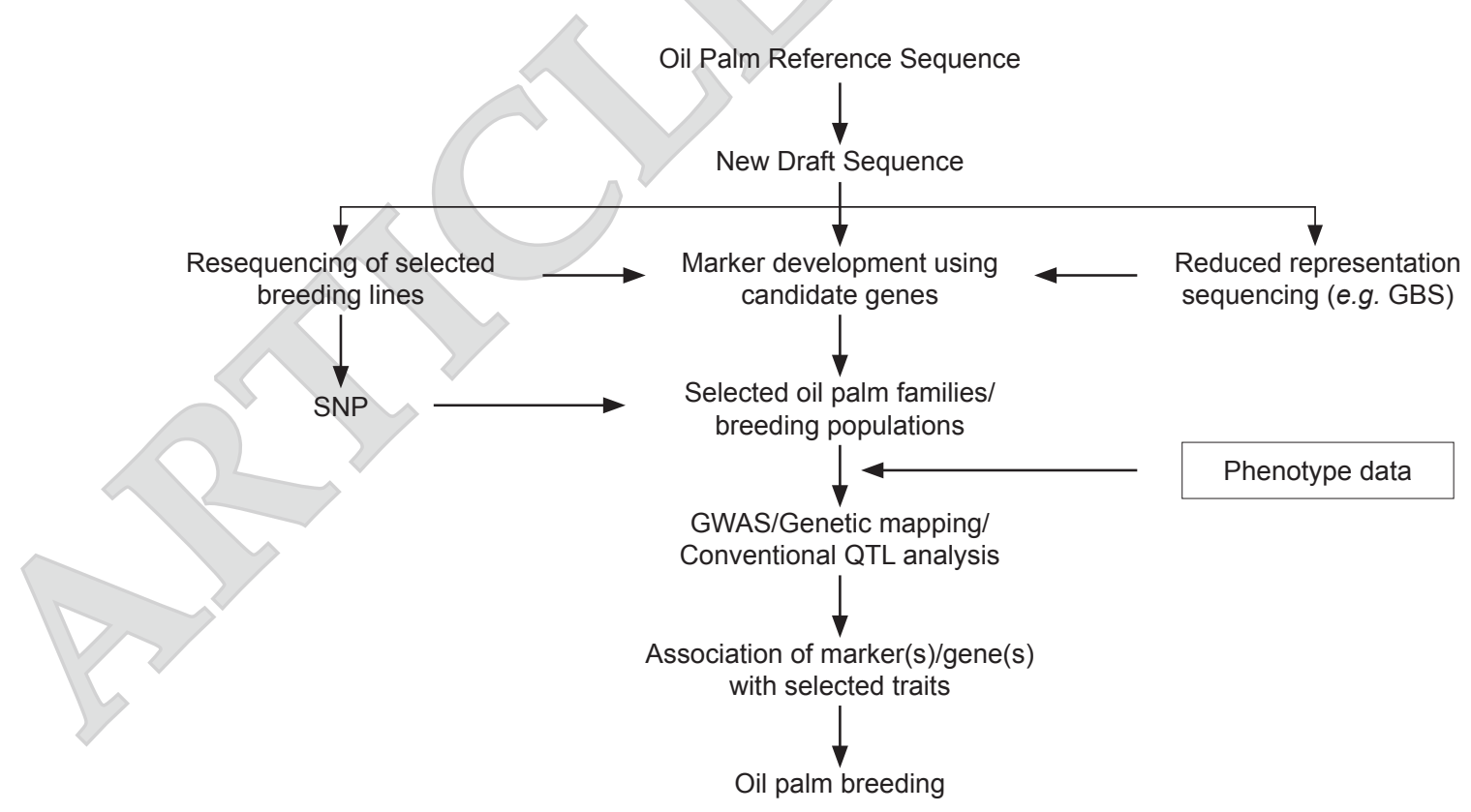

Note: GWAS - Genome Wide Association Study. QTL - Quantitative trait loci.

Figure 1. An overview of the use of the oil palm reference genome for improving oil palm breeding efficiency. The reference genome proved useful as an anchor to establish new draft sequence, resequencing of selected lines which resulted in development of high-density single nucleotide polymorphism (SNP) array. Genotyping by sequencing (GBS) was also made possible as an alternative genotyping tool, which together with SNP arrays, assisted in establishing marker trait association. Interestingly, the availability of large repertoire of sequences also allows development of markers from candidate genes associated with traits in other crop system. 
In proteomics research, all the proteins of a cell, the proteome are studied simultaneously in different physiological situations. It provides a dynamic reflection of genes and environment and offers a novel approach for gene (DNA) identification. Damerval et al. (1994) identified protein quantity loci (PQL) that explained some of the proteins analysed using proteomics for the purpose of implementing marker-assisted selection (MAS) to improve the traits under study. This type of research is particularly useful for breeding programmes as they provide molecular-based clues about nutritional value, yield and observed stress tolerance phenotypes and how these factors are affected by other adverse conditions (Salekdeh and Komatsu, 2007; Chen and Harmon, 2006). In addition, knowledge of key proteins that play a crucial role in the development of a plant has the potential to complement metabolomics to elucidate the biochemistry of the phenotype being expressed (Deshmukh et al., 2014). There are many examples of proteomics-based studies that include the investigation of biotic and abiotic stresses, which negatively affect crop growth and productivity worldwide (Hashiguchi et al., 2010; Bartolini et al., 1999). Proteomics approaches are also useful to explore the molecular mechanisms underpinning plant-microbe interactions (Lodha et al., 2013; Quirino et al., 2010; Mehta et al., 2008). Contrasting samples in respect to temporal protein accumulation during fruit development (e.g., proteins expressed during early versus fruit ripening) or presence in a specific tissue (e.g., proteins exclusively present in leaf, root and stem) have also been studied using proteomics (Bianco et al., 2013; Nozu et al., 2006).

The well-established International Rice Sequencing Protocols have delivered a substantial amount of information, where proteome studies have facilitated the detection of novel traits useful for breeding (Yu et al., 2002). Accordingly, following proteome analysis, a number of previously unknown novel genes coding for enzymes in metabolic pathways were identified in a number of crops (Canovas et al., 2004). Interestingly, proteome analysis of genetically modified crops has also been used to decipher substantial equivalence in comparative safety analysis to help increase the acceptance of transgenic crops and products (Zhao et al., 2013; Barros et al., 2010).

A complete understanding of plant systems requires filling the gap between proteome and phenotype. We can study genes being expressed, and what proteins are present, but the more important question is for instance what makes certain oil palms to be higher yielding than others or why specific oil palms are more tolerant to disease. Metabolomics is perhaps the ultimate level of post-genomic analysis as it can expose changes in metabolite fluxes that are caused by only minor changes in gene expression (Allwood et al., 2008). Metabolomics attempts to measure the complete set of metabolites as the end products of cellular regulatory processes, and their levels can be viewed as the response of biological systems to environment or genetic manipulations (Maloney, 2004). Metabolomics distinguishes what is really occurring in a system, whereas genomics and proteomics recognise what could occur. This fact demands a different perspective and requires the measurement of transcriptional, proteomic and metabolomic data in order to obtain a complete picture of the system's response to genetic or environmental stress stimuli.

There are increasing number of examples indicating that proteome and metabolome profiling approaches are becoming more and more important to explore significant sources of variation in crops caused by genetic background, breeding methods, growing environment, genotype-environment interactions and crop cultural practices (Davies et al., 2010; Dixon et al., 2006). The combination of proteomics and metabolomics is thought of as an advanced profiling technology that broadens the spectrum of detectable compounds, which improves the efficacy of assessment strategies (Barros et al., 2010; Zolla et al., 2008; Metzdorff et al., 2006). Generally, the potential of applying proteomics and metabolomics in research is significant and a brief account of the various approaches in plants is given in Table 1. Nevertheless, proteomics and metabolomics are yet to be utilised directly on a large scale for crop improvement, and the most basic application currently is focussed on gaining an understanding of proteins and metabolites associated with complex traits such as, yield and disease resistance, both of which are major targets of crop breeding (Kumar et al., 2017; Canovas et al., 2004).

\section{TECHNOLOGICAL PERSPECTIVES FOR PROTEOMICS AND METABOLOMICS}

The advent of proteomics technologies for global detection and quantitation of proteins has generated new opportunities and challenges for scientists seeking a deeper insight into the systems biology of an organism. As the proteome more accurately reflects the dynamic state of a cell, tissue or organism, it has huge potential for yielding better markers for crop improvement and monitoring of disease. However, as proteins are much more diverse physically and chemically than nucleic acids, there are several difficulties in the study of proteins that are not inherent in the study of nucleic acids. Furthermore, proteins cannot be amplified like DNA; therefore, less abundant species are more difficult to detect (Van Wijk, 2001). More 
importantly, this technique demands advanced technologies focusing on improved separation, resolution and automation for the identification and characterisation of proteins including the chemical and physical properties of the target proteins.
High throughput proteomics technologies coupled with advanced bioinformatics are increasingly leveraged to identify molecular signatures of economic importance based on protein pathways and signalling cascades.

\section{TABLE 1. EXAMPLE OF INITIATIVES IN PROTEOMICS AND METABOLOMICS AS BIOTECHNOLOGICAL TOOLS FOR} CROP IMPROVEMENT

\begin{tabular}{|c|c|c|c|c|}
\hline Crop & Trait studied & & Tools / techniques & References \\
\hline \multirow[t]{5}{*}{ Olive } & $\begin{array}{l}\text { Tolerance to cold } v s . \text { non-tolerant } \\
\text { after cold treatments }\end{array}$ & Proteomics & Isoelectric focusing (IEF), 2-DE & Bartolini et al. (1999) \\
\hline & Olive pulp proteins & & $\begin{array}{l}\text { Nano-LC/MS/MS, } \\
\text { MALDI-TOF-MS }\end{array}$ & $\begin{array}{l}\text { Capriotti et al. (2013) } \\
\text { Esteve et al. (2011) }\end{array}$ \\
\hline & Geographical characterisation & Metabolomics & NMR & Rongai et al., (2017) \\
\hline & Olive classification & & GC-QTOF/MS & Sales et al. (2017) \\
\hline & $\begin{array}{l}\text { Determination of phenolic } \\
\text { compounds in virgin olive oil }\end{array}$ & & $\begin{array}{l}\text { LC coupled to fluorescence } \\
\text { detector }\end{array}$ & Monasterio et al. (2016) \\
\hline \multirow[t]{8}{*}{ Maize } & $\begin{array}{l}\text { Unintended effects of genetic } \\
\text { modification }(\mathrm{GM})\end{array}$ & Proteomics & 2-DE & $\begin{array}{l}\text { Barros et al. (2010) } \\
\text { Zolla et al. (2008) }\end{array}$ \\
\hline & C4 leaf development & & NanoLC-LTQ-Orbitrap & Majeran et al., (2010) \\
\hline & Ear rot infection & & iTRAQ & Mohammadi et al. (2012) \\
\hline & Seedlings & & LC-MS/MS & Ning et al. (2016) \\
\hline & Greening of leaves & & LC-MS & Shen et al. (2009) \\
\hline & $\begin{array}{l}\text { Genetically modified organism } \\
\text { (GMO) }\end{array}$ & Metabolomics & CE-TOF-MS, FT-ICR-MS & Leon et al. (2009) \\
\hline & Salt stress tolerance & & & Gavaghan et al. (2011) \\
\hline & $\begin{array}{l}\text { Effect of environment and } \\
\text { genotype }\end{array}$ & & LC-N & Baniasadi et al. (2014) \\
\hline \multirow[t]{8}{*}{ Rice } & Etiolated shoot & Prote & 2-DE & Komatsu et al. (1999) \\
\hline & Unintended changes in GM rice & & 2-DE & Zhao et al. (2013) \\
\hline & Rice proteome database & & Shotgun proteogenomics & Helmy et al. (2011) \\
\hline & Stress tolerance & & iTRAQ & Wang et al. (2014) \\
\hline & Chemical diversity & Metabolomics & GC-MS, LC-MS & Kusano et al. (2015) \\
\hline & Rice quality and traceability & & FT-IR, NMR & $\begin{array}{l}\text { Uawisetwathana and } \\
\text { Karoonuthaisiri (2019) }\end{array}$ \\
\hline & GM-rice (insect resistance) & & LC-ESI-Q/TOF MS & Chang et al. (2012) \\
\hline & $\begin{array}{l}\text { Nutritionally enhanced herbicide } \\
\text { tolerance }\end{array}$ & & GC-EI-TOF MS & Kim et al. (2013) \\
\hline \multirow[t]{7}{*}{ Soyabean } & Salt tolerance & Proteomics & MALDI-TOF/TOF & Ma et al. (2012) \\
\hline & $\begin{array}{l}\text { Wild and cultivated soyabean } \\
\text { genotypes }\end{array}$ & & 2-DE, MALDI, LC-MS/MS & Natarajan et al. (2006) \\
\hline & Water and nutrient uptake & & iTRAQ & Nguyen et al. (2012) \\
\hline & Tolerance to Phytophtora & & 2-DE & Zhang et al. (2011) \\
\hline & Drought and heat stress & Metabolomics & GC-MS/LC-MS & Das et al. (2017) \\
\hline & $\begin{array}{l}\text { Response to Rhizoctonia to foliar } \\
\text { blight disease }\end{array}$ & & NMR & Copley et al. (2017) \\
\hline & Transgenic soyabean & & CE-TOF-MS & García-Villalba et al. (2008) \\
\hline \multirow[t]{5}{*}{ Oil palm } & Somatic embryogenesis & Proteomics & 2-DE \& MALDI, TOF-MS/MS & Tan et al. (2016) \\
\hline & Fruit development proteomics & & 2-DE \& MALDI, TOF-MS / MS & Hassan et al. (2019) \\
\hline & Pathogen-studies (Ganoderma) & & LC-MS Orbitrap & Syahanim et al. (2019) \\
\hline & Pathogen-studies (Ganoderma) & Metabolomics & GC-GC-TOF-MS & Rozali et al. (2017) \\
\hline & Phytochemicals & & LC-ESI-TOF-MS & Tahir et al. (2012) \\
\hline
\end{tabular}


In the area of metabolomics research, every technique employed has specific advantages and limitations. Thus, clearly there is no single method that is ideal for all research purposes. Analytical techniques that are most often used for metabolite profiling include nuclear magnetic resonance (NMR) (Nicholson et al., 1999), gas chromatographymass spectrometry (GC-MS) (Roessner et al., 2000), liquid chromatography-mass spectrometry (LC-MS) (Tolstikov et al., 2003; Huhman and Sumner, 2002; Fraser et al., 2000) and capillary electrophoresismass spectrometry (CE-MS) (Sato et al., 2004). Generally, NMR instrument is arguably the most powerful technique for an organic chemist to determine structure in metabolomics research. MS excels at selective identification of a molecular entity, while NMR excels at identification of all proton containing species in a sample. Specifically, interfacing liquid chromatography with parallel MS or NMR (LC-NMR-MS) has been shown to give comprehensive structural data on metabolites of novel drugs in development. Although MS and NMR are the most common tools used for large scale analysis of metabolites whether targeted or non-targeted, metabolomics is not limited to these techniques. Other techniques such as thin layer chromatography (TLC), high performance liquid chromatography (HPLC) with ultraviolet (UV)/ visible absorbance, photodiode array (PDA) or electrochemical detectors, Fourier transforminfrared (FT-IR) and variety of other enzymatic assays have also been widely used to improve metabolite coverage and increase quantification limits (Shulaev, 2006; Gamache et al., 2004; Kristal and Matson, 2002). Generally, specific platforms are not a prerequisite for metabolomics investigations, so in theory, any technique capable of generating comprehensive metabolite measurements can be used for metabolomics.

As seen today, metabolomics employs multiple complementary analytical devices starting from sample preparation to determining the measurement details of all analytical platforms, and finally to corresponding specific steps of data analysis (Table 1). The choice of technique primarily depends on the research strategies and the nature of the samples. Three basic strategies can be used in metabolomics: (i) targeted analysis, (ii) metabolite profiling, and (iii) metabolic fingerprinting (Halket et al., 2004; Fiehn, 2002). These techniques are commonly used to reveal the phenotype of silent mutations (Raamsdonk et al., 2001), studying responses to environmental stress (Huntingford et al., 2005; Rosenblum et al., 2005), assessing global effects of genetic manipulation (Catchpole et al., 2005), comparing different growth / fruit development (Hurtado-Fernández et al., 2015), nutrition (German et al., 2002) and natural product discovery (Fiehn et al., 2001). Specifically, the major analytical technologies driving metabolomics such as LC-MS have enormous potential for metabolite profiling and for analysing selected metabolites as a complement to GC-MS. In addition, NMR spectroscopy has high discriminatory power at the level of metabolic fingerprints. However, NMR fingerprints provide limited information on individual metabolites and therefore purification of the metabolites is required for accurate identification (Jorge et al., 2016; Weckwerth, 2003).

Like other functional genomics research, the future of proteomics and metabolomics lies in the combination of different techniques for identification and quantification of proteins and metabolites to achieve a complete view; no single technique alone can cope with the diversity and structural complexity of the proteome and metabolome. We believe that protein and metabolite analyses are much more powerful when used in combination than individually. Furthermore, the combination of the data generated from proteomics and metabolomics requires specific bioinformatics support in the form of databases, visualisation and data integration to provide a meaningful assessment of the research. A review by Weckwerth (2008) provides the strategy for data integration, which combines high throughput profiling methods with exploratory multivariate data mining. In fact, a combination of computeraided metabolic modelling and multivariate data mining will enable a systematic comparison for identifying key steps involved in metabolism using extensive and multi-dimensional datasets from proteomics, transcriptomics and metabolomics studies (Mehrotra and Mendes, 2006; Morgenthal et al., 2006).

Along with the establishment of a database platform, the streamlined workflow is now available to facilitate research in oil palm proteomics and metabolomics (Figure 2). This includes a combination of approaches, either gel-based or liquid chromatography (gel-free), with tandem mass spectrometry to optimally extract proteins by modifying existing methods described in literature. At present, proteomics technologies are being applied to identify potential biomarkers associated with oil production, fruit ripening, embryogenic lines and disease resistance (Hassan et al., 2019; Lau et al., 2018; Tan et al., 2016; Syahanim et al., 2013; AlObaidi et al., 2017). Looking beyond the proteome, advanced metabolomics technologies also include key elements, starting from sample extraction to profiling of targeted and non-targeted metabolites using multiple technologies, mainly LC and GC coupled to tandem mass spectrometry (Nurazah et al., 2017; Rozali et al., 2017; Tahir et al., 2016; 2012). We foresee that proteomics and metabolomics technologies will play a more significant role in the near future to address diverse issues related to the oil palm in the effort to assist on-going breeding activities to further improve the oil crop. 
An important point to consider is that the large multi-dimensional datasets that result from proteomics and metabolomics require complex and high throughput statistical analysis to render the data meaningful and make rational conclusions in the study. Thus, bioinformatics tools are essential for the efficient processing of huge datasets. Proteomics data also have to be linked to the existing gene, transcripts and ribonucleic acid sequencing (RNAseq) datasets to develop tissue specific expression atlases and proteome maps. Integration of transcriptomics, proteomics as well as metabolomics with genotyping and phenotyping data and establishment of appropriate databases, with the corresponding bioinformatic infrastructure will lead to a functional understanding and improved prediction accuracy of yield and quality parameters for developing sophisticated strategies such as genome-wide MAS to improve breeding efficiency. Although the interpretation of the different 'omics' datasets is not straightforward, the combined information is an important step towards uncovering correlation(s) between the expressed genetic information and the phenotypic response of the oil palm crop.

\section{Charting Proteome-based Knowledge for Improving Oil Palm Yield and Quality}

Increasing oil production of a key crop such as oil palm is essential for a more sustainable and greener future. A better understanding of how plants regulate oil biosynthesis will assist in efforts towards breeding palms that produce more oil, with specific fatty acid compositions which relate to quality (Lau et al., 2018; Ramli et al., 2002a, b). This provides a more sustainable way to produce more of the desired natural oils from existing hectarage instead of simply increasing the area of land used for agriculture. In this respect, several key enzymes and genes involved in the regulation of fatty acid biosynthesis of the oil palm have been characterised and purified, mainly for utilisation in the genetic modification programme (Masura et al., 2017; Ramli et al., 2012; Parveez et al., 2010; Sambanthamurthi et al., 2000). The information is also useful for genomicsbased improvement of the crop. In fact, combining transcriptome and proteome analyses is essential for developing a comprehensive understanding of the molecular mechanisms regulating fruit development and fatty acid metabolism. Several studies which employed gel-based comparative proteomics, provided an overview of proteins that are abundant during oil palm fruit development, as well as insights into proteins that play a key role during fruit maturation. There has been much progress in technologies and chemometrics application that have revealed changes in proteins that accumulate during oil palm mesocarp development (Hassan et al., 2019).

In its early stages, the oil palm fruit consists of storage and structural carbohydrates and

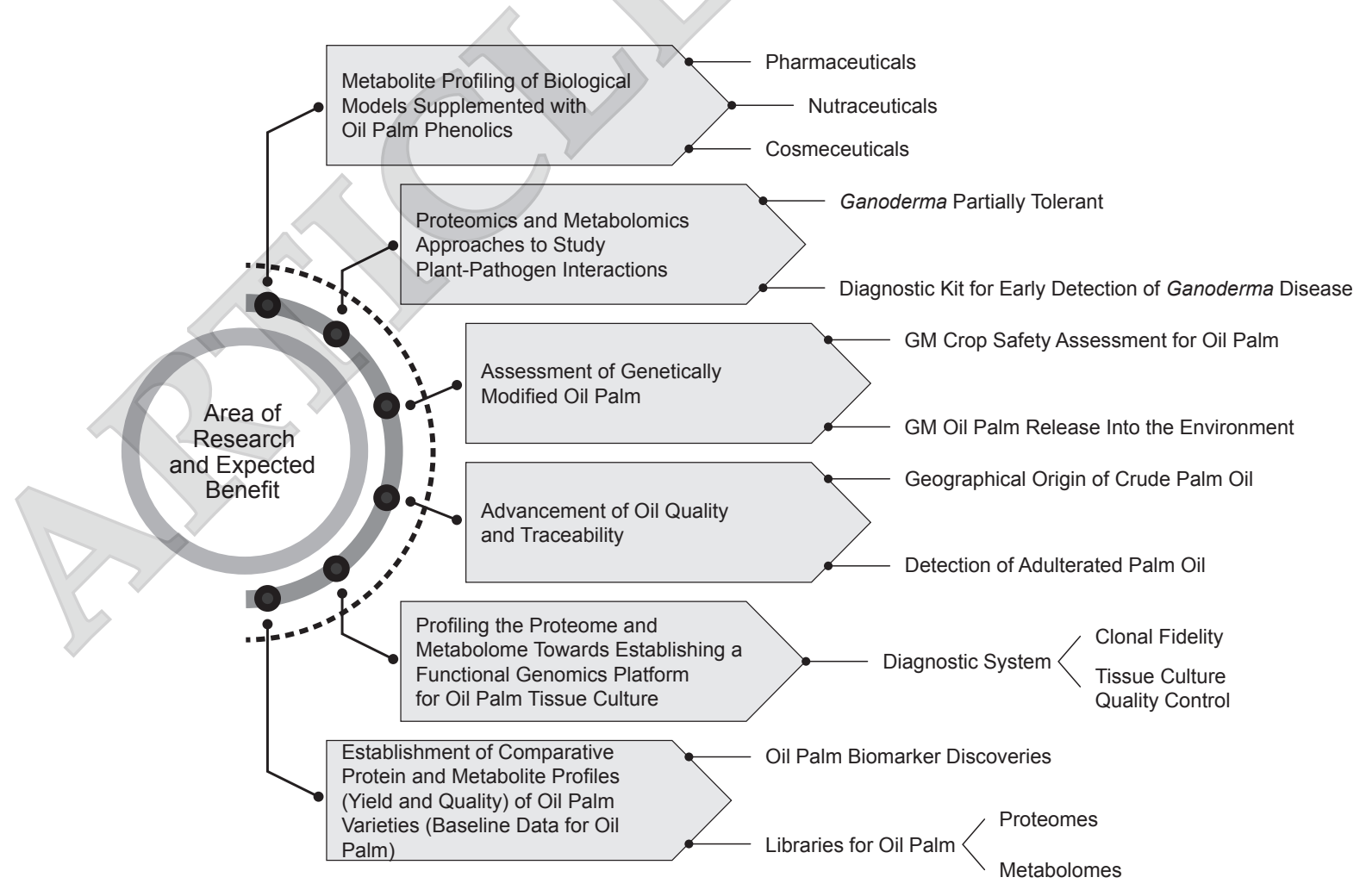

Figure 2. Priority research areas in oil palm proteomics and metabolomics. 
membrane lipids but very little oil. As it approaches maturity, the formation of oil increases rapidly in the mesocarp tissue and the ripeness of the fruit bunch is marked by huge changes in the exocarp tissues. Several targeted and untargeted proteomics and metabolomics studies have been carried out to gain a holistic understanding of molecular mechanisms regulating fruit maturation to complement available genomic information. The metabolomics platform of MS in particular, which results in huge amounts of data has proven useful in the analysis of molecular fractions at specific time points during oil palm fruit development (Teh et al., 2013). Hassan et al. (2019) developed proteomics protocol to study major metabolism including those involved in lipid production, energy, secondary metabolites and amino acid, which were found to be significantly altered during fruit development (Figure 3). Independent research which focused on the analysis of proteins and metabolites from high yielding oil palm and storage oil production (Ooi et al., 2015; Loei et al., 2013; Neoh et al., 2013) has mostly complemented the earlier findings on the different proteins accumulated during fruit development. To further build capacity, more than 4000 proteins have been identified from oil palm fruit mesocarp (Hassan et al., 2014; Lau et al., 2018; 2020) can be catalogued in a database to facilitate future research. In another interesting research, Lau et al. (2015) studying high-oleate palms, described advanced proteomic techniques to isolate, detect and identify chromoplast-based proteins associated with the fatty acid biosynthesis pathway. It was revealed that control of oleic acid production is not restricted to enzymes associated with fatty acid biosynthesis, supporting previous biochemical studies that the flux of fatty acids into most plant oils is controlled in large part by the relative activity of more than one pathway (Ramli et al., 2002b). Lau et al. (2016) also reported the plausibility of phosphorylation involvement in the regulation mechanism.

Using the integrated omics approach, Appleton et al. (2014) discovered that subtle changes in carbon flux can lead to increased oil synthesis in oil palm. They reported that although genetic markers are important for oil palm crop improvement, marker accuracy varies across population backgrounds depending on genetic distance of markers from controlling genes and population diversity. Furthermore, development of accurate marker selection tools is especially challenging for highly polygenic traits like yields that are largely influenced by the environment. There is a recognition that biochemical omics techniques could act as a link between controlling genes and associated genetic markers by determining genes and biochemical pathways that are more directly associated with the final trait. Along this line, the team investigated the differences in biochemical regulation of high yielding individuals compared to average performers within a group of siblings planted in

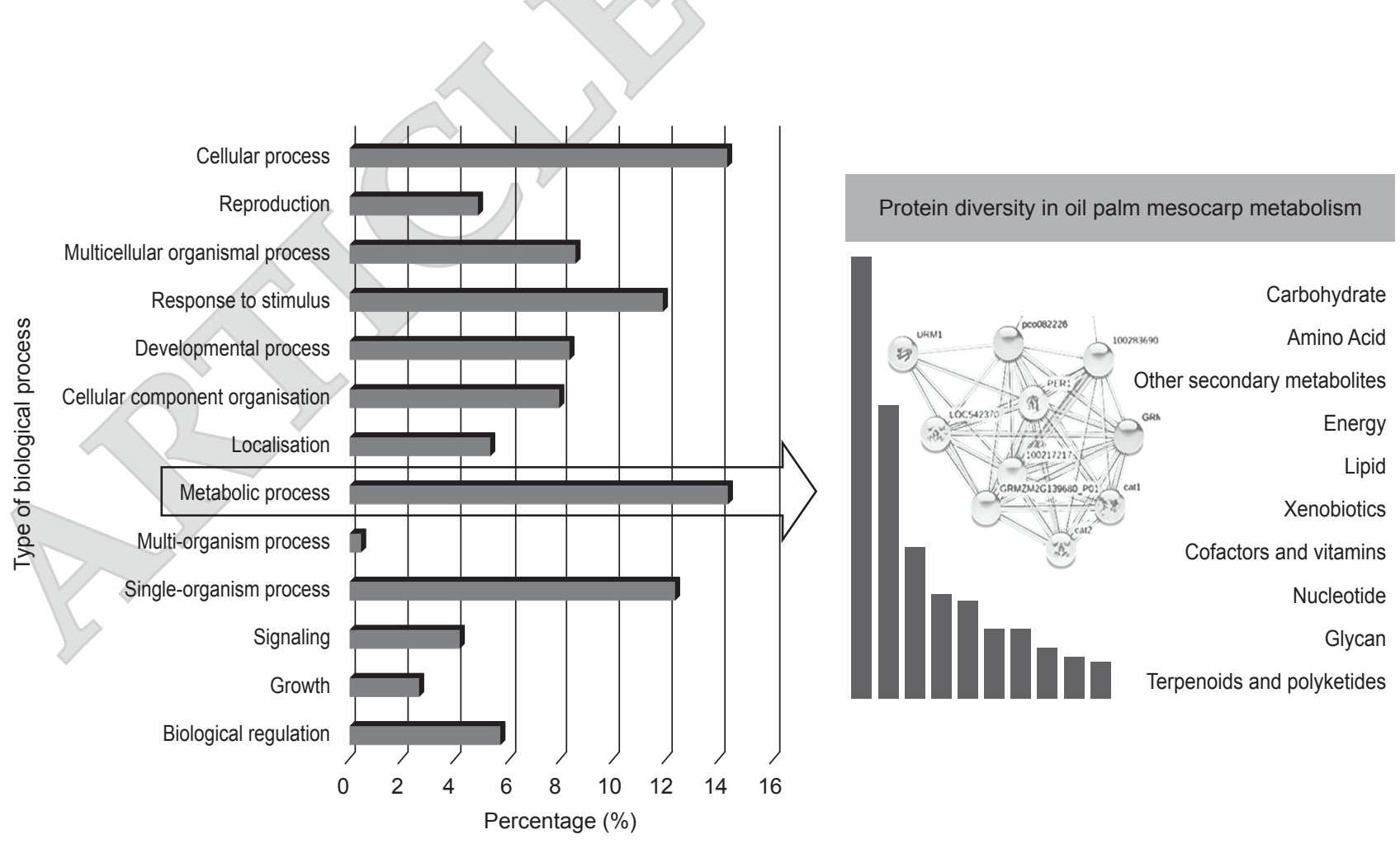

Figure 3. Functional classification of identified proteins from oil palm mesocarp tissue using gel-based proteomics approach (adapted from Hassan et al., 2019). 
the same location. Transcriptomics, proteomics and metabolomics were used to compare biochemical changes before, during and after oil biosynthesis in the mesocarp to obtain further understanding of regulation of oil biosynthesis in the oil palm. Genome polymorphisms associated with the genes identified were subsequently prioritised when conducting genome-wide association studies on larger sets of more diverse populations.

Teh et al. (2014) investigated changes in expression of polyamines, hormones and cellwall-related genes, and metabolites in the oil palm mesocarp at different stages of fruit development and described the relationship between the structural and biochemical metabolism during ripening. A distinct reduction in auxin-responsive gene expression was observed from 18 to 22 weeks after anthesis. Fruit enlargement during lipid accumulation and later stage of fruit maturation coincided with high polyamine concentrations. Actin, expansin and polygalacturonase gene expressions were also observed to increase during fruit maturation. The combined omics approach provided a more detailed understanding of the coordinated process involved in fruit ripening and oil accumulation and could potentially lead to the identification of the master regulators of these important processes.

Oil palm and date palm exhibit an extreme difference in carbon partitioning, with oil palm accumulating high amount of oil in its mesocarp, and the closely related date palm accumulating almost exclusively sugars. Bourgis et al. (2011) compared the transcriptome and metabolite content of oil palm and date palm and discovered that despite more than a 100-fold difference in flux to lipids, most enzymes of triacylglycerol assembly were expressed at similar levels in oil palm and date palm. Oil palm had much higher transcript levels for all fatty acid synthesis enzymes, and transcripts of an orthologue of the WRI1 transcription factor were 57-fold higher in oil palm compared to date palm. The combination of transcriptomics and metabolomics confirmed earlier flux studies by Ramli et al. (2002a, b; 2009) that fatty acid synthesis plays a more predominant role than triacylglycerol assembly in the regulation of lipid synthesis in oil palm.

\section{Deciphering the Molecular Interactions in Oil} Palm Disease Using Proteomics and Metabolomics

The most important oil palm diseases are basal stem rot (BSR) (Ganoderma spp.), Fusarium vascular wilt (Fusarium oxysporum f.sp. elaeidis), red ring (Rhadinaphelenchus cocophilus), Phytoplasma sudden wilt (Phytomonas staheli), Phyhthoptora bud rot (Phyhthoptora palmivora), Marchitez/lethal wilt (Phytoplasma sp), Cercospora leaf spot (Cercospora elaeidis) and chlorotic ring (Potyvirus) (Ariffin et al., 2000; Flood, 2006; Chinchilla, 1988; Torres et al., 2010; Di Lucca et al., 2013; Weir, 1968; Morales et al., 2002). In Malaysia and other oil palm producing countries in South-east Asia, Ganoderma boninense is the dominant fungal pathogen responsible for BSR disease in Elaeis guineensis (Idris et al., 2011; Susanto et al., 2005; Turner and Gillbanks, 2003). Statistical data revealed that in Malaysia, losses due to Ganoderma disease can reach up to RM 1.5 million a year (Arif et al., 2011) and it was estimated that the total area affected by Ganoderma disease in 2020 would be around 443430 ha or 65.6 million of oil palms (Roslan and Idris, 2012). As yet no effective remedial method to prevent spread of the disease to healthy stands has been reported (Idris et al., 2016).

As palm oil represents the largest share of the world's vegetable oil market, $80 \%$ of which is used by the food industry, BSR may have a serious effect on global food security. Continuous efforts have been made to select tolerant oil palm progenies (Idris et al., 2004; Durand-Gasselin et al., 2005) or to develop best management practices to control the spread of the disease (Susanto et al., 2005). Metabolomics tools have been used to explore metabolite profiles in highly tolerant and susceptible genetic backgrounds to improve our current understanding of its biology. Although it is still preliminary, the developed method provides a basic tool as a standard protocol for future efforts aimed at selective breeding of oil palm via metabolomics-assisted breeding techniques (Rozali et al., 2017). The Deli palms (in Malaysia and Indonesia) are more susceptible to Ganoderma than those from the African germplasm (Cameroon) (Idris et al., 2004). The elucidation of potential metabolite markers, i.e. shikimic acid, glucose and malic acid that were responsible for separately clustering Deli and MPOB-Cameroon duras as highlighted by Nurazah et al. (2017) provides an initial clue into what may distinguish susceptible and tolerant planting materials. The results suggest that the employed methodology is a powerful approach to profile and portray leaf metabolome with different susceptibility to $G$. boninense. In the future, we envision additional studies that incorporate metabolomics as well as other different omics platforms for screening larger populations of truly resistant and susceptible palms, to obtain a holistic view of oil palm's response to Ganoderma, with a view to conduct detailed pathway analysis.

The use of omics technologies to better understand incidences of BSR in oil palm has been reported recently (Othman et al., 2019a). The assignment of fatty acid composition in oil palm leaves in relation to severity of Ganoderma infection, and protein analysis of $G$. boninense using gel- and LC-based approaches are examples of how 
proteomics and metabolomics studies are contributing to improve our current understanding of BSR (Othman et al., 2017; Dzulkafli et al., 2019; Nurazah et al., 2013). Due to its great potential, proteomics specifically has been used to better understand the pathogen, Ganoderma spp. itself (Syahanim et al., 2019; Dzulkafli et al., 2016). The identification of differential proteins in two Ganoderma spp., namely G. boninense (pathogenic) and G. tornatum (non-pathogenic) will prove invaluable in understanding virulence and pathogenicity (Al-Obaidi et al., 2016). This will also help in long-term efforts at elucidating the mechanisms of how the fungus infects oil palm. Protein identification depends not only on analytical technologies but also on the existence of complete genome sequence databases for comparison. The genome sequence information for this phytopathogen was recently published by a joint group of researchers from France and Malaysia who assembled a total of $63 \mathrm{Mb}$ using Illumina and 454 platforms to identify microsatellite markers for genetic diversity studies (Mercière et al., 2015). More recently, additional information on the sequence and number of reads generated for G. boninense and G. tornatum samples were also reported (Nagappan et al., 2018).

\section{Omics - A Tool to Assist in the Generation and Assessment of Transgenic Oil Palm}

The identification of genes regulating specific traits will play a key role towards the improvement of the oil palm, with potential application in modifying oil content and fatty acid composition by genetic engineering (Parveez et al., 2015; Ramli et al., 2012; Othman et al., 2000) and managing the Ganoderma disease (Mohamad Arif et al., 2017; Safiza et al., 2015; Lim et al., 2017; Rasid et al., 2014). Despite its economic importance, authorisation and commercialisation of genetically modified organism (GMO) has always been controversial within the scientific and public communities. The advancements in omics technologies are tremendously useful both to facilitate the generation and safety assessment of transgenic crops. First and foremost, omics platforms, especially the transcriptome data, are highly valuable for establishing the basic genetic resources required in the genetic engineering efforts. Identification and isolation of key genes, proteins or promoters are very much simplified. This is illustrated by several recent publications. On promoter isolation, Siti Suriawati et al. (2019) reported the identification of a gene that was highly expressed in mesocarp tissue through in silico analysis of oil palm transcriptome datasets. The expression specificity of the gene in the tissue was confirmed by real-time quantitative polymerase chain reaction ( $\mathrm{qPCR}$ ) analysis. Using a similar approach, potential root specific genes were also identified (Masura et al., 2019a). Identification of these tissue-specific sequences is crucial for the isolation of their promoter sequences and ultimately for directing the expression of transgenes into the desired tissues.

The application of transcriptome data has also led to the identification and isolation of a number of constitutive promoters from oil palm (Masura et al., 2019b; 2011). In addition, omics data have also led to the identification of several indicative sequences and metabolites that are associated with several traits of interest (Masura et al., 2017). All of these findings could potentially be used in the genetic engineering of oil palm. Oil palm is known to be recalcitrant to genetic transformation, and as such, the development of genotype-independent transformation technology is crucial for this crop. This could help improve oil palm transformation efficiency, which currently is quite low. One approach is through the use of Baby boom $(\mathrm{Bbm})$ and Wuschel2 (Wus2) genes, which can help establish a biological context to improve transformation efficiency.

The availability of oil palm omics data, especially transcriptome analysis of various tissues and development stages has facilitated the identification and isolation of key genes, which are being selectively applied in research related to genetic modification of oil palm (Masani et al., 2018). The existing omics information also has huge potential for utilisation in the exciting area of genome editing. Genome editing offers several advantages over the conventional genetic engineering protocols. First, the technique results in a more predictable and precise gene modification. Since the technique does not add any external or foreign sequence to the recipient cells, it is also more readily acceptable to consumers as well as regulatory authorities. Research on the application of this in oil palm has already been initiated (Bahariah et al., 2019), and will likely open up opportunities for genome editing-based improvement. The availability of omics data would facilitate the efforts in two primary ways. First, the omics data would allow more accurate prediction of the target locations. This would minimise the possibilities of off targets in the resultant modified plants. Besides, the data are also useful for the identification of the target or key genes. Increasing oleic acid content has been the main objective of oil palm genetic engineering research at MPOB. Extensive studies to identify the target genes and important regulatory controls over the biosynthesis pathway have been carried out and reviewed (Parveez et al., 2015). This has resulted in the formulation of a comprehensive strategy to produce high oleic oil palms through conventional genetic engineering. However, the immense omics 
data will allow even more comprehensive analysis of the fatty acid biosynthesis or other pathways.

The analysis will not only allow for the identification of target sequences of the pathway and discrimination of different isoforms but could also determine the crucial elements that are not directly involved in the pathway, such as transcription factors. For example, Dussert et al. (2013) identified paralogues of the WRINKLED1 transcription factors that were highly expressed during oil deposition in the oil palm mesocarp and endosperm. Manipulation of these regulatory elements has proven to be effective in a number of recent studies. For example, overexpression of transcription factors GmDof4 and GmDof11 was shown to increase the oleic acid content of Brassica napus seeds (Sun et al., 2018). Similarly, oil content of peanut seeds was significantly increased through overexpression of the transcription factor AtLEC1 (Tang et al., 2018). In tomato, lycopene content was increased up to 5.1-fold through CRISPR/Cas9 multiplex genome editing. It was further illustrated that the regulator protein SGR1 has a greater control over the lycopene accumulation compared to a number of enzymes in the carotenoid biosynthesis pathway (Li et al., 2018).

Gene editing is also relevant in the field of pests and diseases. A number of recent reports have demonstrated the feasibility of manipulating regulatory sequences to create disease or pest resistant or tolerant plants. For example, genetic manipulation of the disease susceptibility gene CsLOB1 through CRISPR/Cas9 technique produced plants that are resistant to citrus canker. The CsLOB1 is a member of the Lateral Organ Boundaries Domain (LBD) gene family of plant transcription factors that can be recognised and induced by the pathogen transcription activator-like (TAL) effectors (Jia et al., 2017). Another example is demonstrated by the increased tolerance to rice blast using transcription factor OsSRF922. Mutation of the gene through CRISPR/Cas9 has resulted in significant decrease in pathogen infection in all mutant lines tested (Wang et al., 2016). Initial development in this area has also started to take place in oil palm. Studies to unravel the interaction between oil palm and its most serious pathogen G. boninense have been carried out and reported using transcriptomic, proteomic and metabolomic analyses (Ho et al., 2016; Nusaibah et al., 2016; Al-Obaidi et al., 2016; Syahanim et al., 2013). The findings from these studies will eventually contribute towards creating Ganoderma tolerant oil palm.

As the research for developing genetically modified (GM) oil palm pushes forward, omics platforms will be essential to confirm that only the intended genomic alterations have occurred. Analysis of the genome, proteome and metabolome will increase the chances of detecting unintended effects, if any (Gong and Wang, 2013). As an example, the proteomics-based analysis of the GM round-up ready soyabean revealed no significant alteration in the expression of allergens following genetic modification. Similarly, Gong et al. (2012) showed that genetic modification did not alter the protein profile of rice compared to those produced via conventional breeding. However, other studies have shown differences between GM products and non-GM controls (Luo et al., 2009). Metabolomics analysis showed significant difference in selected metabolites between the conventional and GM insect resistant maize (Levandi et al., 2008). The differences observed are likely due to exogenous gene(s) being inserted and the site(s) where the insertion occurs among other factors (Gong and Wang, 2013). This demonstrates the important role of omics-based platforms in evaluating GM oil palm in the near future.

\section{Integrative Omics for Understanding Oil Palm Seed Germination}

Despite the critical importance of germination of oil palm seeds, our knowledge on the physiology of the process is limited. Most metabolic studies were carried out in the 1980s and there has been little advancement in our knowledge of molecular players and metabolic controls involved in germination. Oil palm seeds have a low germination rate because of a long dormancy attributed to restrictions of embryo growth because of the hard endocarp which results in mechanical constraints and resistance to oxygen absorption. The germination of oil palm seeds can take years, under natural conditions. Elevated temperature and appropriate levels of seed moisture are necessary for rapid and optimal germination. For commercial seed production, oil palm seeds are heat treated under controlled conditions to break dormancy. However, the effect of heat treatment on phytohormone-related genes/ proteins/metabolites and possible relationship with dormancy release is not well understood. Wang et al. (2019) carried out integrative omics analysis on the phytohormones involved in oil palm seed germination under conditions used for commercial production to discover the mechanisms involved in oil palm seed germination. Differentially expressed genes and proteins (DEG and DEP) related to seed germination were identified using RNA-seq and isobaric tags for relative and absolute quantitation (iTRAQ) and the results validated with qPCR and western blot. LC-MS/MS was used to determine endogenous phytohormones while exogenous phytohormones were also applied to validate their effects on seed germination. The authors confirmed the important role of phytohormones in oil palm seed germination with abscisic acid (ABA) acting as an inhibitor. Heat treatment breaks dormancy at 
least partly by eliminating endogenous ABA. The results emphasised how the omics platforms of transcriptomics, proteomics and metabolomics in combination led to an improved understanding of oil palm seed germination.

Although key metabolic pathways such as $\beta$-oxidation are common in germination of all oleaginous seeds including oil palm, palm seeds have unique attributes such as the involvement of the haustorium that digests the endosperm and eventually invades the seed (Cui et al., 2020). This involves important metabolic processes such as fatty acid transport and coenzyme A cycling. Despite the importance of these aspects, advances in germination metabolism have been scarce. It is increasingly obvious that integrated omics approaches will be key in resolving the complex processes underpinning germination. Functional genomics will identify gene functions and interactions relevant to seed germination. Proteomics analyses will be of importance to find key transporters, confirm the localisation of enzymes involved in mobilisation of reserves including but not limited only to lipids, and identify proteins associated with kernel oil bodies. Metabolomics may help unravel the spatial and temporal profile of metabolites in the various tissues of the germinating seed. This was recently achieved for maize (Feenstra et al., 2017). Such information will be useful for identifying molecular markers associated with superior germination performance which will be advantageous for oil palm breeding.

\section{Geographical and Authentication Tracing of Palm Oil Using Omics-based Technologies}

Ensuring food safety requires the monitoring of its source of production and distribution throughout the supply chain. This will enable a sound certification system and also prevent the introduction of adulterants or contaminants during the production and processing stage (Goggin and Murphy, 2018). The ability to distinguish palm oil from different regions or sources requires the development of a geographical traceability system by using robust and precise methods that allow the palm oil consignment to be traced back to its origin at every phase of production. The attempt to differentiate palm oil according to its geographical source has been explored using a wide range of omics tools. These tools include advanced analytical techniques such as GC-flame ionisation detector (GC-FID), proton transfer reaction-MS (PTRMS), UV-visible spectroscopy, elemental analyser coupled to an isotope ratio mass spectrometer (EAIRMS), HPLC and GC-ion mobility spectrometry (GC-IMS) combined to cheminformatics of principle component analysis (PCA), partial least squaresdiscriminant analysis (PLS-DA), orthogonal partial least squares-discriminant analysis (OPLS-
DA), hierarchical cluster analysis (HCA) and soft independent modelling of class analogy (SIMCA) (Ramli et al., 2020). Promising markers that can facilitate geographical differentiation of palm oil include fatty acid profiles, triacylglycerols, volatile organic compounds, isotopic composition, phytosterols and carotenoid content, in combination with chemometrics (Goggin and Murphy, 2018; Tres et al., 2013; Muhammad et al., 2018). The possibility of utilising genomics-based DNA fingerprints of palm oil is also being explored due to its success in differentiating other vegetable oils (Costa et al., 2012). However, the ability of DNA markers to track palm oil samples across the supply chain to their geographical origin is going to be challenging, as genotypes with different genetic backgrounds are usually planted, even in a single block of a large plantation (Ramli et al., 2020; Ooi et al., 2006). Nevertheless, the work is important to detect and nail down fraudulent and unsafe milling and processing activities, if any. With the current technological capabilities, metabolomics is also being exploited for identifying unique chemical fingerprints to detect product contamination and adulteration. This effort is actively being conducted in order to position the oil palm industry to meet and optimise the delivery of the highest quality oil with minimum environmental and social concerns. Efforts are being directed to specifically look into the potential of technologies to ensure that palm oil, especially crude palm oil (CPO) and refined palm oil meet international standards including those related to 3-monochloropropane-1,2-diol (3-MCPD) (Tarmizi et al., 2019). Adherence to the practice of not adding sludge palm oil (SPO) or other residual oils, such as palm fibre oil (PFO) back to the CPO, will help maintain the Malaysian palm oil industry at the forefront of the vegetable oils and fats industry. Omics-based technologies can be applied to ensure that $\mathrm{CPO}$ is free from such residual oils. This was demonstrated in a recent study, where GC-IMS was used for rapid and cost-effective screening of $\mathrm{CPO}$ for detection of PFO and SPO based on their characteristic volatile organic compound (VOC) fingerprints. The study demonstrated that the identification of contaminants, adulterations and/ or off flavours at very low concentrations is possible in CPO samples (Othman et al., 2019b). This paves the way for this technology to be used for quality assurance and eventually for product traceability.

\section{CONCLUSION}

Genomic platforms represent a key resource towards achieving the target of producing superior oil palm. However, understanding the cellular biology and biochemistry underlying the specific traits is no substitute for studying proteins and 
metabolites, since these are directly responsible for cellular activity. Therefore, to complete the view offered by genomics and transcriptomic-based analysis, proteomics and metabolomics offer a new comprehensive perspective to better understand regulatory mechanisms that govern complex phenotypes, especially those under environmental influence. As such, an integrated omics approach is essential to uncover the complexities and diverse physiological processes that govern complex traits in the oil palm (e.g. yield, quality and disease resistance), which can lead to biomarkers that can more accurately predict these traits. Undeniably, proteomics and metabolomics research on oil palm is still at its infancy and there is a need for further development of relevant methods and techniques for comprehensive analysis of proteins and metabolites towards understanding complex traits in oil palm. Although challenges are aplenty, on-going technical improvements will facilitate application of integrated omics technologies in developing new and improved oil palm varieties. The pressure of upholding sustainability in a situation where resources are limited warrants a shift in paradigm for the oil palm industry. At this juncture, strict regulations including risk assessment of transgenic oil palm, and making sure $\mathrm{CPO}$ is free of adulterants require established analytical tools that can be adopted by the industry. Thus, new technological advances which can provide fast and robust detection for quality and eventually traceability purposes, cannot be overemphasised. The application of these techniques to agricultural systems is a step forward towards the implementation of translational proteomics and metabolomics in crop breeding. The integration of multi-layered omics data will allow for reconstruction of regulatory networks and provide a stereoscopic view of dynamic molecular processes and interacting networks of genes in the oil palm. This will lead to deeper insights into target traits and facilitate precision breeding of the oil palm.

\section{ACKNOWLEDGEMENT}

The authors wish to thank members of the Proteomics and Metabolomics Unit, Advanced Biotechnology and Breeding Centre, MPOB for their technical assistance.

\section{REFERENCES}

Al-Obaidi, J R; Hussin, S N I S; Saidi, N B; Rahmad, $\mathrm{N}$ and Idris, A S (2017). Comparative proteomic analysis of Ganoderma species during in vitro interaction with oil palm root. Physiol. Mol. Plant P., 99: 16-24.
Al-Obaidi, J R; Saidi, N B; Usuldin, S R A; Rahmad, N; Zean, N B and Idris, A S (2016). Differential proteomic study of oil palm leaves in response to in vitro inoculation with pathogenic and nonpathogenic Ganoderma spp. J. Plant Pathol. Vol. 98(2): 235-244.

Alam, A F; Er, A C and Begum, H (2015). Malaysian oil palm industry: Prospect and problem. J. Food Agric. Environ., 13(2): 143-148.

Allwood, J W; Ellis, D I and Goodacre, R (2008). Metabolomic technologies and their application to the study of plants and plant-host interactions. Physiol. Plant., 132(2): 117-135.

Appleton, D R; Teh, H F; Neoh, B K; Ooi, E K; Wong, Y C and Kulaveerasingam, H (2014), Omics reveals subtle changes in carbon flux that lead to increased oil biosynthesis in oil palm. Inform Magazine AOCS May 2014. https://www.aocs.org/stay-informed/ inform-magazine / featured-articles / omics-revealssubtle-changes-in-carbon-flux-that-lead-toincreased-oil-biosynthesis-in-oil-palm

Arif, M S; Roslan, A and Idris, A S (2011). Economics of oil palm pests and Ganoderma disease and yield losses. Proc. of the Third MPOB-IOPRI International Seminar: Integrated Oil Palm Pests and Diseases Management. 14 November 2011. Kuala Lumpur Convention Centre.

Ariffin, D; Idris, A S and Singh, G (2000). Status of Ganoderma in oil palm. Ganoderma Diseases of Perennial Crops (Flood, J; Bridge, P D and Holderness, M eds.). p. $49-68$.

Bahariah, B; Masani, MY A; Rasid, O A; Parveez; G K A; Tang, Y; Ji, Z; Wei, Z; Wang, C and Zhao, K (2019). CRISPR/Cas9-mediated genome editing of FAD2 gene in rice: A monocotyledonous model plant for oil palm. Proc. of the PIPOC 2019 International Palm Oil Congress. MPOB, Bangi. p. 30-34.

Bai, B; Wang, L; Lee, M; Zhang, Y; Alfiko, Y; Ye, B Q; Wan, Z Y; Lim, C H; Suwanto, A; Chua, N-H and Yue, G H (2017). Genome-wide identification of markers for selecting higher oil content in oil palm. BMC Plant Biol., 17(1): 93.

Baniasadi, H; Vlahakis, C; Hazebroek, J; Zhong, C and Asiago, V (2014). Effect of environment and genotype on commercial maize hybrids using LC/ MS-based metabolomics. J. Agr. Food Chem., 62(6): 1412-1422.

Barros, E; Lezar, S; Anttonen, M J; Van Dijk, J P; Röhlig, R M; Kok, E J and Engel, K H (2010). Comparison of two GM maize varieties with a near- 
isogenic non-GM variety using transcriptomics, proteomics and metabolomics. Plant Biotechnol. J., 8(4): 436-451.

Bartolini, G; Di Monte, G; Rea, E and Toponi, M A (1999). Protein patterns in response to cold stress on clones of Olea europaea L., cv Leccino. Acta Hortic., 474: 481-484.

Bianco, L; Alagna, F; Baldoni, L; Finnie, C; Svensson, B and Perrotta, G (2013). Proteome regulation during Olea europaea fruit development. PLOS ONE, 8(1): e53563.

Billotte, N; Marseillac, N; Risterucci, A M; Adon, B; Brottier, P; Baurens, F C; Singh, R; Herran, A; Asmady, H; Billot, C and Amblard, P (2005). Microsatellite-based high density linkage map in oil palm (Elaeis guineensis Jacq.). Theor. App. Genet., 110(4): 754-765.

Bourgis, F; Kilaru, A; Cao, X; Ngando-Ebongue, G-F; Drira, N; Ohlrogge, J B and Vincent Arondel, V (2011). Comparative transcriptome and metabolite analysis of oil palm and date palm mesocarp that differ dramatically in carbon partitioning. PNAS, 108(30): 12527-12532.

Canovas, F M; Dumas-Gaudot, E; Recorbet, G; Jorrin, J; Mock, H P and Rossignol, M (2004). Plant proteome analysis. Proteomics, 4(2): 285298.

Capriotti, A L; Cavaliere, C; Foglia, P; Piovesana, S; Samperi, R; Stampachiacchiere, S and Laganà, A (2013). Proteomic platform for the identification of proteins in olive (Olea europaea) pulp. Anal. Chim. Acta, 800: 36-42.

Catchpole, G S; Beckmann, M; Enot, D P; Mondhe, M; Zywicki, B; Taylor, J; Hardy, N; Smith, A; King, R D; Kell, D B; Fiehn, O and Draper, J (2005). Hierarchical metabolomics demonstrates substantial compositional similarity between genetically modified and conventional potato crops. Proc. of the Natl. Acad. Sci. USA, 102(40): 14458-14462.

Chan, P L; Ma, L S; Low, E T L; Shariff, E M; Ooi, L C L; Cheah, S C and Singh, R (2010). Normalized embryoid cDNA library of oil palm (Elaeis guineensis). Electron. J. Biotechnol., 13(1): 1011.

Chang, Y; Zhao, C; Zhu, Z; Wu, Z; Zhou, J; Zhao, Y; Lu, $X$ and $X u, G$ (2012). Metabolic profiling based on LC/MS to evaluate unintended effects of transgenic rice with cry1Ac and sck genes. Plant Mol. Biol., 78: 477-487.
Chaudhary, J; Patil, G B; Sonah, H; Deshmukh, R K; Vuong, T D; Valliyodan, B and Nguyen, H T (2015). Expanding omics resources for improvement of soybean seed composition traits. Front. Plant Sci., 6: 1021-1037.

Cheah, S C; Maria, M; Ooi, L C; Rahimah, A R and Siti Nor Akmar, A (1993). Detection of DNA variability in the oil palm using RFLP probes. Proc. of the PIPOC 1993 International Palm Oil Congress. 9-14 September 1993, Kuala Lumpur, Malaysia.

Chen, S and Harmon, A C (2006). Advances in plant proteomics. Proteomics, 6(20): 5504-5516.

Chinchilla, C M (1988). The red ring-little leaf syndrome in oil palm and coconut. Bol. Tec Opo-CB, 2(4): 113-136.

Copley, T R; Aliferis, K A; Kliebenstein, D J and Jabaji, S H (2017). An integrated RNAseq-1 H NMR metabolomics approach to understand soybean primary metabolism regulation in response to Rhizoctonia foliar blight disease. BMC Plant Biol., 17(1): 84 .

Costa, J; Mafra I and Oliveira, M B P P (2012). Advances in vegetable oil authentication by DNAbased markers. Trends Food Sci. Technol., 26(1): 4355.

Cui, J; Lamade, E and Tcherkez, G (2020). Seed germination in oil palm (Elaeis guineensis Jacq.): A review of metabolic pathways and control mechanisms. Int. J. Mol. Sci., 21(12): 4227.

Damerval, C; Maurice, A; Josse, J M and De Vienne, D (1994). Quantitative trait loci underlying gene product variation: A novel perspective for analyzing regulation of genome expression. Genetics, 137(1): 289-301.

Das, A; Rushton, P and Rohila, J (2017). Metabolomic profiling of soybeans (Glycine max L.) reveals the importance of sugar and nitrogen metabolism under drought and heat stress. Plants, 6(2): 21.

Davies, H V; Shepherd, L V; Stewart, D; Frank, T; Röhlig, R M and Engel, K H (2010). Metabolome variability in crop plant species - When, where, how much and so what? Regul. Toxicol. Pharmacol., 58(3): S54-S61.

Deshmukh, R; Sonah, H; Patil, G; Chen, W; Prince, S; Mutava, R; Vuong, T; Valliyodan, B and Nguyen, H T (2014). Integrating omic approaches for abiotic stress tolerance in soybean. Front. Plant Sci., 3(5): 244. DOI: 10.3389 / fpls.2014.00244. 
Di Lucca, A G T; Trinidad Chipana, E F; Talledo Albújar, M J; Dávila Peralta, W; Montoya Piedra, Y C and Arévalo Zelada, J L (2013). Slow wilt: Another form of Marchitez in oil palm associated with trypanosomatids in Peru. Trop. Plant Patho., 38(6): 522-533.

Dixon, R A; Gang, D R; Charlton, A J; Fiehn, O; Kuiper, H A; Reynolds, T L; Tjeerdema, R S; Jeffery, E H; German, J B; Ridley, W P and Seiber, J N (2006). Applications of metabolomics in agriculture. J. Agric. Food Chem., 54(24): 8984-8994.

Durand-Gasselin, T; Asmady, H; Flori, A; Jacquemard, J C; Hayun, Z; Breton, F and De Franqueville, H (2005). Possible sources of genetic resistance in oil palm (Elaeis guineensis Jacq.) to basal stem rot caused by Ganoderma boninense Prospects for future breeding. Mycopathologia, 159(1): 93-100.

Dussert, S; Guerin, C; Andersson, M; Joët, T; Tranbarger, TJ; Pizot, M; Sarah, G; Omore, A; DurandGasselin, T and Morcillo, F (2013). Comparative transcriptome analysis of three oil palm fruit and seed tissues that differ in oil content and fatty acid composition. Plant Physiol., 162(3): 1337-1358.

Dzulkafli, S B; Othman, A; Shahwan, S; Nurazah, Z; Manaf, M A A; Idris, A S; Amiruddin, M D; Tahir, N I and Ramli, U S (2019). Identification of chelidonic acid and asparagine in Ganoderma boninenseinoculated oil palm seedlings. J. Oil Palm Res. Vol. 31(1): 53-66.

Dzulkafli, S B; Othman, A; Lau, B Y C; Shahwan, S; Idris, A S and Ramli, U S (2016). Optimization of protein extraction from Ganoderma boninense for sodium dodecyl sulfate-polyacrylamide gel electrophoresis (SDS-PAGE) analysis. Transactions of Persatuan Genetik Malaysia. p. 193-197.

Eldakak, M; Milad, S I M; Nawar, A I and Rohila, J $S$ (2013). Proteomics: A biotechnology tool for crop improvement. Front. Plant Sci., 4(35): 1-12.

Esteve, C; Cañas, B; Moreno-Gordaliza, E; Del Río, C; García, M C and Marina, M L (2011). Identification of olive (Olea europaea) pulp proteins by matrix-assisted laser desorption/ionization time-of-flight mass spectrometry and nano-liquid chromatography tandem mass spectrometry. J. Agric. Food Chem., 59(22): 12093-12101.

Feenstra, A D; Alexander, L E; Song, Z; Korte, A R; Yandeau-Nelson, M D; Nikolau, B J and Lee, Y J (2017). Spatial mapping and profiling of metabolite distributions during germination. Plant Physiol., 174: 2532-2548.
Fernie, A R and Schauer, N (2009). Metabolomicsassisted breeding: A viable option for crop improvement? Trends Genet., 25(1): 39-48.

Fiehn, O (2002). Metabolomics - The link between genotypes and phenotypes. Functional Genomics. Springer, Dordrecht. p. 155-171.

Fiehn, O; Kloska, S and Altmann, T (2001). Integrated studies on plant biology using multiparallel techniques. Curr. Opin. Biotechnol., 12(1): 82-86.

Flood, J (2006). A review of Fusarium wilt of oil palm caused by Fusarium oxysporum f. sp. elaeidis. Phytopathology, 96(6): 660-662.

Fraser, PD; Pinto, ME S; Holloway, D E and Bramley, P M (2000). Application of high-performance liquid chromatography with photodiode array detection to the metabolic profiling of plant isoprenoids. Plant J., 24(4): 551-558.

Gamache, P H; Meyer, D F; Granger, M C and Acworth, I N (2004). Metabolomic applications of electrochemistry/mass spectrometry. J. Am. Soc. Mass Spectrom., 15(12): 1717-1726.

García-Villalba, R; León, C; Dinelli, G; SeguraCarretero, A; Fernández-Gutiérrez, A; Garcia-Cañas, $\mathrm{V}$ and Cifuentes, $\mathrm{A}(2008)$. Comparative metabolomic study of transgenic versus conventional soybean using capillary electrophoresis-time-of-flight mass spectrometry. J. Chromatogr. A, 1195: 164-173.

Gavaghan, C L; Li, J V; Hadfield, S T; Hole, S; Nicholson, J K; Wilson, I D; Howe, P W A; Stanley, P D and Holmes, E (2011). Application of NMRbased metabolomics to the investigation of salt stress in maize (Zea mays). Phytochem. Anal., 22(3): 214-224.

German, J B; Roberts, M A; Fay, L and Watkins, S M (2002). Metabolomics and individual metabolic assessment: The next great challenge for nutrition. J. Nutr., 132(9): 2486-2487.

Glaab, E (2016). Using prior knowledge from cellular pathways and molecular networks for diagnostic specimen classification. Brief. Bioinform., 17(3): 440-452.

Goggin, K A and Murphy, D J (2018). Monitoring the traceability, safety and authenticity of imported palm oils in Europe. OCL, 25: A603.

Gong, C Y; Li, Q; Yu, H T; Wang, Z and Wang, T (2012). Proteomics insight into the biological safety of transgenic modification of rice as compared with conventional genetic breeding and 
spontaneous genotypic variation. J. Proteome Res., 11(5): 3019-3029.

Gong, CY and Wang, T (2013). Proteomic evaluation of genetically modified crops: Current status and challenges. Front. Plant Sci., 4: 41.

Hajduch, M; Matusova, R; Houston, N L and Thelen, J J (2011). Comparative proteomics of seed maturation in oilseeds reveals differences in intermediary metabolism. Proteomics, 11(9): 16191629.

Halket, J M; Waterman, D; Przyborowska, A M; Patel, R K P; Fraser, P D and Bramley, P M (2004). Chemical derivatization and mass spectral libraries in metabolic profiling by GC/MS and LC/MS/MS. J. Exp. Bot., 56(410): 219-243.

Hashiguchi, A; Ahsan, N and Komatsu, S (2010). Proteomics application of crops in the context of climatic changes. Food Res. Int., 43(7): 1803-1813.

Hassan, H; Amiruddin, M D; Weckwerth, W and Ramli, U S (2019). Deciphering key proteins of oil palm (Elaeis guineensis Jacq.) fruit mesocarp development by proteomics and chemometrics. Electrophoresis, 40(2): 254-265.

Hassan, H; Lau, B Y C and Ramli, U S (2014). Extraction methods for analysis of oil palm leaf and root proteins by two-dimensional gel electrophoresis. J. Oil Palm Res. Vol. 26(1): 54-61.

Helmy, M; Tomita, M and Ishihama, Y (2011). OryzaPG-DB: Rice proteome database based on shotgun proteogenomics. BMC Plant Biol., 11(1): 63 .

Ho, C L; Kwan, Y Y; Choi, M C; Tee, S S; Ng, W H; Lim, K A; Lee, Y P; Ooi, S E; Lee, W W; Tee, J M and Tan, S H (2007). Analysis and functional annotation of expressed sequence tags (ESTs) from multiple tissues of oil palm (Elaeis guineensis Jacq.). BMC Genomics, 8(1): 381.

Ho, C L; Tan, Y C; Yeoh, K A; Ghazali, A K; Yee, W Y and Hoh, C C (2016). De novo transcriptome analyses of host-fungal interactions in oil palm (Elaeis guineensis Jacq.). BMC Genomics, 17(1): 66.

Huhman, D V and Sumner, L W (2002). Metabolic profiling of saponins in Medicago sativa and Medicago truncatula using HPLC coupled to an electrospray ion-trap mass spectrometer. Phytochemistry, 59(3): 347-360.
Huntingford, C; Hugo Lambert, F; Gash, J HC; Taylor, C M and Challinor, A J (2005). Aspects of climate change prediction relevant to crop productivity. Philos. T. R. Soc. B., 360(1463): 1999-2009.

Hurtado-Fernández, E; Pacchiarotta, T; Mayboroda, O A; Fernández-Gutiérrez, A and Carrasco-Pancorbo, A (2015). Metabolomic analysis of avocado fruits by GC-APCI-TOF MS: Effects of ripening degrees and fruit varieties. Anal. Bioanal. Chem., 407(2): 547-555.

Idris, A S; Nurrashyeda, R; Mohd Hefni, R; Samala, S and Norman, K (2016). Standard Operating Procedures (SOP) Guidelines for Managing Ganoderma Disease in Oil Palm. MPOB, Bangi. p. 41.

Idris, A S; Mior, M HAZ; Maizatul, SM and Kushairi, A (2011). Survey on status of Ganoderma disease of oil palm. Proc. of the PIPOC 2011 International Palm Oil Congress. MPOB, Bangi. p. 235-238.

Idris, A; Kushairi, A; Ismail, S and Ariffin, D (2004). Selection for partial resistance in oil palm progenies to Ganoderma basal stem rot. J. Oil Palm. Res. Vol. 16(2): 12-18.

Jia, H; Zhang, Y; Orbović, V; Xu, J; White, F F; Jones, J B and Wang, N (2017). Genome editing of the disease susceptibility gene CsLOB1 in citrus confers resistance to citrus canker. Plant Biotechnol. J., 15(7): 817-823.

Jin, J; Lee, M; Bai, B; Sun, Y; Qu, J; Rahmadsyah; Alfiko, Y; Lim, C H; Suwanto, A; Sugiharti, M; Wong, L; Ye, J; Chua, N-H and Yue, G H (2016). Draft genome sequence of an elite Dura palm and wholegenome patterns of DNA variation in oil palm. DNA Research, 23(6): 527-533.

Jorge, T F; Mata, A T and António, C (2016). Mass spectrometry as a quantitative tool in plant metabolomics. Philos. Trans. A Math. Phys. Eng. Sci., 374(2079): 20150370. http://dx.doi.org/10.1098/ rsta.2015.0370

Jouannic, S; Argout, X; Lechauve, F; Fizames, C; Borgel, A; Morcillo, F; Aberlenc-Bertossi, F; Duval, Y and Tregear, J (2005). Analysis of expressed sequence tags from oil palm (Elaeis guineensis). FEBS Lett., 579(12): 2709-2714.

Khosla, P. (2011). Nutritional characteristics of palm oil. Reducing Saturated Fats in Foods. Woodhead Publishing. p. 112-127.

Kim, J K; Park, S-Y; Lee, S M; Lim, S-H; Kim, H J; Oh, S-D; Yeo, Y; Cho, H S and Ha, S-H (2013). Unintended polar metabolite profiling of carotenoid-biofortified 
transgenic rice reveals substantial equivalence to its non-transgenic counterpart. Plant Biotechnol. Rep., 7(1): 121-128.

Komatsu, S; Muhammad, A and Rakwal, R (1999). Separation and characterization of proteins from green and etiolated shoots of rice (Oryza sativa L.): Towards a rice proteome. Electrophoresis, 20(3): 630636.

Kristal, B S and Matson, W R (2002). Simultaneous analysis of multiple redox-active metabolites from biological matrices. Oxidative Stress Biomarkers and Antioxidant Protocols. Humana Press. p. 185-194.

Kumar, R; Bohra, A; Pandey, A K; Pandey, M K and Kumar, A (2017). Metabolomics for plant improvement: Status and prospects. Front. Plant Sci., 8: 1302.

Kusano, M; Yang, Z; Okazaki, Y; Nakabayashi, R; Fukushima, A and Saito, K (2015). Using metabolomic approaches to explore chemical diversity in rice. Mol. Plant, 8(1): 58-67.

Kushairi, A; Ong-Abdullah, M; Nambiappan, B; Hishamuddin, E; Bidin, M N I Z; Ghazali, R; Subramaniam, V; Sundram, S and Parveez, G K A (2019). Oil palm economic performance in Malaysia and R\&D progress in 2018. J. Oil Palm Res.Vol. 31(2): 165-194.

Kwong, Q B; Teh, C K; Ong, A L; Heng, H Y; Lee, H L; Mohamed, M; Low, J Z-B; Apparow, S; Chew, F T; Mayes, S; Kulaveerasingam, H; Tammi, M and Appleton, D R (2016). Development and validation of a high-density SNP genotyping array for African oil palm. Mol. Plant, 9(8): 1132-1141.

Lau, B Y C; Othman, A and Ramli, U S (2018). Application of proteomics technologies in oil palm research. Protein J., 37(6): 473-499.

Lau, B Y C; Deb-Choudhury, S; Morton, J D; Clerens, S; Dyer, J M and Ramli, U S (2015). Method developments to extract proteins from oil palm chromoplast for proteomic analysis. SpringerPlus, 4(1): 791.

Lau, B Y C; Clerens, S; Morton, J D; Dyer, J M; DebChoudhury, S and Ramli, US (2016). Application of a mass spectrometric approach to detect the presence of fatty acid biosynthetic phosphopeptides. Protein J., 35(2): 163-170.

Lau, B Y C; Amiruddin, M D and Othman, A (2020). Proteomics analysis on lipid metabolism in Elaeis guineensis and Elaeis oleifera. Data in Brief., 31: 105714.
Leon, C; Rodriguez-Meizoso, I; Lucio, M; GarciaCañas, V; Ibañez, E; Schmitt-Kopplin, $\mathrm{P}$ and Cifuentes, A (2009). Metabolomics of transgenic maize combining Fourier transform-ion cyclotron resonance-mass spectrometry, capillary electrophoresis-mass spectrometry and pressurized liquid extraction. J. Chromatogr. A, 1216(43): 73147323.

Levandi, T; Leon, C; Kaljurand, M; Garcia-Cañas, V and Cifuentes, A (2008). Capillary electrophoresis time-of-flight mass spectrometry for comparative metabolomics of transgenic versus conventional maize. Anal. Chem., 80(16): 6329-6335.

Li, Y; Fang, T; Zhu, S; Huang, F; Chen, Z and Wang, Y (2018). Detection of olive oil adulteration with waste cooking oil via Raman spectroscopy combined with iPLS and SiPLS. Spectrochim. Acta A. Mol. Biomol. Spectrosc., 189: 37-43.

Lim, F-H; Fakhrana, I N; Rasid, O A; Idris, A S; Ho, C-L; Shaharuddin, N A and Parveez, G K A (2017). Molecular cloning and expression analysis of Ganoderma boninense cyclophilins at different growth and infection stages. Physiol. Mol. Plant P., 99: 31-40.

Lodha, T D; Hembram, P and Nitile Tep, J B (2013). Proteomics: A successful approach to understand the molecular mechanism of plant-pathogen interaction. Am. J. Plant Sci., 4(06): 1212.

Loei, H; Lim, J; Tan, M; Lim, T K; Lin, Q S; Chew, F T; Kulaveerasingam, H and Chung, M C M (2013). Proteomic analysis of the oil palm fruit mesocarp reveals elevated oxidative phosphorylation activity is critical for increased storage oil production. J. Proteome Res., 12(11): 5096-5109.

Long, Y; Shi, J; Qiu, D; Li, R; Zhang, C; Wang, J; Hou, J; Zhao, J; Shi, L and Park, B-S (2007). Flowering time quantitative trait loci analysis of oilseed Brassica in multiple environments and genomewide alignment with Arabidopsis. Genetics, 177(4): 2433-2444.

Low, E T L; Alias, H; Boon, S H; Shariff, E M; Tan, C Y A; Ooi, L C; Cheah, S C; Raha, A R; Wan, K L and Singh, R (2008). Oil palm (Elaeis guineensis Jacq.) tissue culture ESTs: Identifying genes associated with callogenesis and embryogenesis. BMC Plant Biology, 8(1): 62.

Low, E T L; Rosli, R; Jayanthi, N; Azizi, N; Chan, K L; Maqbool, N J; Maclean, P; Brauning, R; McCulloch, A; Moraga, R and Ong-Abdullah, M (2014). Analyses of hypomethylated oil palm gene space. PLoS ONE, 9(1): e86728. 
Low, E T L; Jayanthi, N; Chan, K L; Mohd, N S N; Angel, L; Ong-Abdullah, M; Singh, R; Manaf, M A A; Sambanthamurthi, R and Parveez, G K A (2017). The oil palm genome revolution. J. Oil Palm Res. Vol. 29(4): 456-468.

Luo, J; Ning, T; Sun, Y; Zhu, J; Zhu, Y; Lin, Q and Yang, D (2009). Proteomic analysis of rice endosperm cells in response to expression of hGM-CSF. J. Proteome Res., 8(2): 829-837.

Ma, H; Song, L; Shu, Y; Wang, S; Niu, J; Wang, Z; Yu, T; Gu, W and Ma, H (2012). Comparative proteomic analysis of seedling leaves of different salt tolerant soybean genotypes. J. Proteomics, 75(5): 1529-1546.

Maizura, I; Rajanaidu, N; Zakri, A H and Cheah, S C (2006). Assessment of genetic diversity in oil palm (Elaeis guineensis Jacq.) using Restriction Fragment Length Polymorphism (RFLP). Genet. Resour. Crop Evol., 53(1): 187-195.

Majeran, W; Friso, G; Ponnala, L; Connolly, B; Huang, M; Reidel, E; Zhang, C; Asakura, Y; Bhuiyan, N H; Sun, Q; Turgeon, R and Van Wijk, K J (2010). Structural and metabolic transitions of C4 leaf development and differentiation defined by microscopy and quantitative proteomics in maize. Plant Cell, 22(11): 3509-3542.

Maloney, V (2004). Plant metabolomics. BioTeach. J., 2: 92-99.

Masani, M Y A; Izawati, A M D; Rasid, O A and Parveez, G K A (2018). Biotechnology of oil palm: Current status of oil palm genetic transformation. Biocatal. Agric. Biotechnol., 15: 335-347.

Masura, S S; Parveez, G K A and Low, E T L (2011). Isolation and characterization of an oil palm constitutive promoter derived from a translationally control tumor protein (TCTP) gene. Plant Physiol. Biochem., 49(7): 701-708.

Masura, S S; Rasid, O A; Noor Azmi, S; Masani, M Y A; Mohd Puad, A; Azzreena, M A and Parveez, G K A (2019a). Mining of transcriptome data for rootspecific promoters from oil palm. Proc. of the PIPOC 2019 International Palm Oil Congress. MPOB, Bangi. p. 495-499.

Masura, S S; Parveez, G K A and Rasid, O A (2019b). Isolation of an oil palm constitutive promoter derived from ubiquitin extension protein (UEP2) gene. J. Oil Palm. Res. Vol. 31(1): 28-41.

Masura, S S; Tahir, N I; Rasid, O A; Ramli, U S; Othman, A; Masani, M Y A; Parveez, G K A and Kushairi, A (2017). Post-genomic technologies for the advancement of oil palm research. J. Oil Palm Res. Vol. 29(4): 469-486.

May, C Y and Nesaretnam, K (2014). Research advancements in palm oil nutrition. Eur. J. Lipid Sci. Technol., 116(10): 1301-1315.

Mayes, S; Jack, P L; Corley, R H V and Marshall, D F (1997). Construction of a RFLP genetic linkage map for oil palm (Elaeis guineensis Jacq.). Genome, 40(1): 116-122.

Mayes, S; James, C M; Horner, S F; Jack, P L and Corley, R H V (1996). The application of restriction fragment length polymorphism for the genetic fingerprinting of oil palm (E. guineensis Jacq.). Mol. Breeding, 2(2): 175-180.

Mehrotra, B and Mendes, P (2006). Bioinformatics approaches to integrate metabolomics and other systems biology data. Plant Metabolomics (Saito, K; Dixon, R A and Willmitzer, L eds.). Springer Berlin, Heidelberg, Germany. p. 105-115

Mehta, A; Brasileiro, A C M; Souza, D S L; Romano, E; Campos, M A; Grossi-De-Sá, M F; Silva, M S; Franco, O L; Fragoso, R R and Bevitori, R (2008). Plant-pathogen interactions: What is proteomics telling us? FEBS J., 275(15): 3731-3746.

Mercière, M; Laybats, A; Carasco-Lacombe, C; Tan, J S; Klopp, C; Durand-Gasselin, T; Alwee, S S R S; Camus-Kulandaivelu, L and Breton, F (2015). Identification and development of new polymorphic microsatellite markers using genome assembly for Ganoderma boninense, causal agent of oil palm basal stem rot disease. Mycol. Prog., 14(11): 103.

Metzdorff, S B; Kok, E J; Knuthsen, P and Pedersen, J (2006). Evaluation of a non-targeted 'omic' approach in the safety assessment of genetically modified plants. Plant Biol., 8(05): 662672.

Mirza, B; Wang, W; Wang, J; Choi, H; Chung, N C and Ping, P (2019). Machine learning and integrative analysis of biomedical big data. Genes, 10(2): 87.

Misra, B B; Langefeld, C; Olivier, M and Cox, L A (2019). Integrated omics: Tools, advances and future approaches. J. Mol. Endocrinol., 62(1): R21-R45.

Mohamad Arif, A M; Izawati, A M D; Zubaidah, R; Masani, A M Y; Safiza, M; Lim, F H; Nurniwalis, A W; Rasid, O A and Parveez, G K A (2017). Biotechnology for diversification and improved resilience of the oil palm. The Planter, 93(1093): 237249. 
Mohammadi, H; Soltani, A; Sadeghipour, H R and Zeinali, E (2012). Effects of seed aging on subsequent seed reserve utilization and seedling growth in soybean. Int. J. Plant Prod., 5(1): 65-70.

Monasterio, R; Olmo-García, L; Bajoub, A; Fernández-Gutiérrez, A and Carrasco-Pancorbo, A (2016). Potential of LC coupled to fluorescence detection in food metabolomics: Determination of phenolic compounds in virgin olive oil. Int. J. Mol. Sci., 17(10): 1627.

Morales, F J; Lozano, I; Sedano, R; Castaño, M and Arroyave, J (2002). Partial characterization of a potyvirus infecting African oil palm in South America. J. Phytopathology, 150(4-5): 297-301.

Morgenthal, K; Weckwerth, W and Steuer, R (2006). Metabolomic networks in plants: Transitions from pattern recognition to biological interpretation. Biosystems, 83(2-3): 108-117.

Muhammad, S A; Seow, E K; Omar, A M; Rodhi, A M; Hassan, H M; Lalung, J; Lee, S C and Ibrahim, B (2018). Variation of $\delta 2 H, \delta 180 \& \delta 13 \mathrm{C}$ in crude palm oil from different regions in Malaysia: Potential of stable isotope signatures as a key traceability parameter. Sci. Jus., 58: 59-66.

Murphy, D (2014). The future of oil palm as a major global crop: Opportunities and challenges. J. Oil Palm Res. Vol. 26(1): 1-24.

Nagappan, J; Chin, C F; Angel, LP L; Cooper, R M; May, S T and Low, E T L (2018). Improved nucleic acid extraction protocols for Ganoderma boninense, G. miniatocinctum and G. tornatum. Biotechnol. Lett., 40(11-12): 1541-1550.

Nambiappan, B; Ismail, A; Hashim, N; Ismail, N; Nazrima, S; Idris, N A N; Omar, N; Saleh, K; Hassan, N A M and Kushairi, A (2018). Malaysia: 100 years of resilient palm oil economic performance. J. Oil Palm Res. Vol. 30(1): 13-25.

Natarajan, S S; Xu, C; Bae, H; Caperna, T J and Garrett, W M (2006). Characterization of storage proteins in wild (Glycine soja) and cultivated (Glycine max) soybean seeds using proteomic analysis. J. Agr. Food Chem., 54(8): 3114-3120.

Neoh, B K; Teh, H F; Ng, T L M; Tiong, S H; Thang, Y M; Ersad, M A; Mohamed, M; Chew, F T; Kulaveerasingam, $\mathrm{H}$ and Appleton, D R (2013). Profiling of metabolites in oil palm mesocarp at different stages of oil biosynthesis. J. Agr. Food Chem., 61(8): 1920-1927.
Nguyen, T H N; Brechenmacher, L; Aldrich, J T; Clauss, T R; Gritsenko, M A; Hixson, K K; Libault, M; Tanaka, K; Yang, F; Yao, Q; Pas a-Tolic, L; Xu D; Nguyen H T and Stacey G (2012). Quantitative phosphoproteomic analysis of soybean root hairs inoculated with Bradyrhizobium japonicum. Mol. Cell Proteomics, 11(11): 1140-1155.

Nicholson, J K; Lindon, J C and Holmes, E (1999). 'Metabonomics': Understanding the metabolic responses of living systems to pathophysiological stimuli via multivariate statistical analysis of biological NMR spectroscopic data. Xenobiotica, 29(11): 1181-1189.

Nielsen, R; Paul, J S; Albrechtsen, A and Song, Y S (2011). Genotype and SNP calling from nextgeneration sequencing data. Nat. Rev. Genet., 12(6): 443-451.

Ning, D-L; Liu, K-H; Liu, C-C; Liu, J-W; Qian, C-R; Yu, Y; Wang, Y-F; Wang, Y-C and Wang, B-C (2016). Large-scale comparative phosphoprotein analysis of maize seedling leaves during greening. Planta, 243(2): 501-517.

Nozu, Y; Tsugita, A and Kamijo, K (2006). Proteomic analysis of rice leaf, stem and root tissues during growth course. Proteomics, 6(12): 3665-3670.

Nurazah, Z; Idris, A S; Kushairi, A; Amiruddin, M D; Othman, A and Ramli, U S (2017). Metabolomics unravel differences between Cameroon Dura and Deli Dura oil palm (Elaeis guineensis Jacq.) genetic backgrounds against basal stem rot. J. Oil Palm Res. Vol. 29(2): 227-241.

Nurazah, Z; Idris, A S; Kushairi, A and Ramli, U $S$ (2013). Metabolite profiling of oil palm towards understanding basal stem rot (BSR) disease. J. Oil Palm Res. Vol. 25(1): 58-71.

Nusaibah, S A; Siti Nor Akmar, A; Idris, A S; Sariah, $M$ and Mohamad Pauzi, Z (2016). Involvement of metabolites in early defense mechanism of oil palm (Elaeis guineensis Jacq.) against Ganoderma disease. Plant Physiol. Biochem., 109: 156-165.

Ong-Abdullah, M; Ordway, J M; Jiang, N; Ooi, S E; Kok, S Y; Sarpan, N; Azimi, N; Hashim, A T; Ishak, Z; Rosli, S K; Malike, F A; Abu Bakar, N A; Marjuni, M; Abdullah, N; Yaakub, Z; Mohd Din, A; Nookiah, R; Singh, R; Low, E T L; Chan, K L; Azizi, N; Smith, S W; Bacher, B; Budiman, M A; Van Brunt, A; Wischmeyer, C; Beil, M; Hogan, M; Lakey, N; Lim, C C; Arulandoo, X; Wong, C K; Choo, C N; Wong, W C; Kwan, Y Y; Syed Alwee, S S R; Sambanthamurthi, R and Martienssen, R A (2015). 
Loss of karma transposon methylation underlies the mantled somaclonal variant of oil palm. Nature, 525: 533-537.

Ong, P W; Maizura, I; Marhalil, M; Rajanaidu, N; Abdullah, N A P; Rafii, M Y; Ooi, L C L; Low, E T $\mathrm{L}$ and Singh, R (2018). Association of SNP markers with height increment in MPOB-Angolan natural oil palm populations. J. Oil Palm Res. Vol. 30(1): 6170.

Ooi, T E K; Yeap, W C; Daim, L D J; Ng, B Z; Lee, F C; Othman, A M; Appleton, D R; Chew, F T and Kulaveerasingam, H (2015). Differential abundance analysis of mesocarp protein from high- and lowyielding oil palms associates non-oil biosynthetic enzymes to lipid biosynthesis. Proteome Sci., 13(1): 28.

Ooi, L C L; Singh, R and Cheah, S C (2006). Detection of DNA in Crude Palm Oil. Project Completion (Viva) Report. MPOB, Bangi.

Othman, A; Lazarus, C; Fraser, T and Stobart, K (2000). Cloning of a palmitoyl-acyl carrier protein thioesterase from oil palm. Biochem. Soc. Trans., 28(6): 619-622.

Othman, A; Bohari, B; Nurazah, Z; Syahanim, S; Mohamad Arif, A M; Idris, A S; Marjuni, M; Amiruddin, M D and Ramli, U S (2017). Fatty acid composition levels in oil palm leaves in relation to severity of Ganoderma infection. Proc. of the PIPOC 2017 International Palm Oil Congress., MPOB, Bangi. p. $94-96$.

Othman, A; Goggin, K A; Tahir, N I; Brodrick, E; Singh, R; Sambanthamurthi, R; Parveez, G K A; Davies, A N; Murad, A J; Muhammad, N H and Ramli, U S (2019a). Use of headspace-gas chromatography-ion mobility spectrometry to detect volatile fingerprints of palm fibre oil and sludge palm oil in samples of crude palm oil. BMC Res. Notes, 12(1): 229. https://doi.org/10.1186/ s13104-019-4263-7

Othman, A; Rasid, O A; Nagappan, J; Low, E T L; Lim, F H; Nurazah, Z; Shahwan, S; Dzulkafli, S B; Rozali, N L; Bohari, B; Angel, L P L; Tahir, N I; Idris, A S; Marjuni, M; Shamala, S; Amiruddin M D; Ramli, U S and Mohamad Arif, A M (2019b). Molecular characterisation of oil palm responses to Ganoderma infection. International Seminar on Breeding for Ganoderma Tolerance in Oil Palm. p. 137-146.

Parveez, G K A; Ong-Abdullah, M; Hasan, Z A A; Hishamuddin, E; Loh, S K; Zanal Bidin, M N I; Salleh, K M; Sundram, S and Idris, Z (2020). Oil palm economic performance in Malaysia and R\&D progress in 2019. J. Oil Palm. Res. Vol. 32(2): 159-191. DOI: https: / / doi.org/10.21894/jopr.2020.0032.

Parveez, G K A; Rasid, O A; Masani, M Y A and Sambanthamurthi, R (2015). Biotechnology of oil palm: Strategies towards manipulation of lipid content and composition. Plant Cell Rep., 34(4): 533543.

Parveez, G K A; Othman, A; Nurhafizah, R and Bahariah, B (2010). Functional analysis of oil palm palmitoyl-ACP thioesterase (FatB) gene via downregulation in a model plant: Arabidopsis thaliana. J. Oil Palm Res. Vol. 22: 803-813.

Pootakham, W; Jomchai, N; Ruang-Areerate, P; Shearman, J R; Sonthirod, C; Sangsrakru, D; Tragoonrung, S and Tangphatsornruang, S (2015). Genome-wide SNP discovery and identification of QTL associated with agronomic traits in oil palm using genotyping-by-sequencing (GBS). Genomics, 105(5): 288-295.

Price, N D; Magis, A T; Earls, J C; Glusman, G; Levy, R; Lausted, C; McDonald, D T; Kusebauch, U; Moss, C L; Zhou, Y and Qin, S (2017). A wellness study of 108 individuals using personal, dense, dynamic data clouds. Nat. Biotechnol., 35(8): 747.

Quirino, B F; Candido, E S; Campos, P F; Franco, O L and Krüger, R H (2010). Proteomic approaches to study plant-pathogen interactions. Phytochem., 71(4): 351-362.

Raamsdonk, L M; Teusink, B; Broadhurst, D; Zhang, $\mathrm{N}$; Hayes, A; Walsh, M C; Berden, J A; Brindle, K M; Kell, D B and Rowland, J J (2001). A functional genomics strategy that uses metabolome data to reveal the phenotype of silent mutations. Nat. Biotechnol., 19(1): 45-50.

Ramli, U S; Tahir, N I; Rozali, N L; Othman, A; Muhammad, N H; Muhammad, S A; Tarmizi, A H A; Hashim, N; Sambanthamurthi, R; Singh, R; Manaf, M A A and Parveez, G K A (2020). Sustainable palm oil - The role of screening and advanced analytical techniques for geographical traceability and authenticity verification. Molecules, 25: 2927.

Ramli, U S; Lau, B Y C; Tahir, N; Shahwan, S; Hassan, H; Nurazah, Z; Rozali, N L; Dzulkafli, S; Ishak, N A and Othman, A (2016). Proteomics and metabolomics: Spearheading oil palm improvement and sustainability. The Planter, 92(1087): 727-737.

Ramli, U S; Sambanthamurthi, R; Rasid, O A; Parveez G K A; Mohamad Arif A M; Othman, A; Yunus, A M; Choo, C S; Alwee, S S R S 
and Abdullah, S N A (2012). The isolation and characterisation of oil palm (Elaeis guineensis Jacq.) $\beta$-ketoacyl-acyl carrier protein (ACP) synthase (KAS) II cDNA. J. Oil Palm Res. Vol. 24: 1480-1491.

Ramli, U S; Baker, D S; Quant, P A and Harwood, J L (2002a). Control mechanisms operating for lipid biosynthesis differ in oil palm (Elaeis guineensis Jacq.) and olive (Olea europaea L.) callus cultures. Biochem. J., 364(2): 385-391.

Ramli, U S; Baker, D S; Patti, A and Harwood, J L (2002b). Control analysis of lipid biosynthesis in tissue cultures from oil crops shows that flux control is shared between fatty acid synthesis and lipid assembly. Biochem. J., 364(2): 393-401.

Ramli, U S; Salas, J J; Quant, P A and Harwood, J L (2009). Use of metabolic control analysis to give quantitative information on control of lipid biosynthesis in the important oil crop, Elaeis guineensis (oil palm). New Phytologist., 184(2): 330-339.

Rasid, O A; Lim, F-H; Noor Azmi, S; Fakhrana, I N; Idris, A S and Parveez, G K A (2014). Isolation of a partial cDNA clone coding for Ganoderma boninense pde. J. Oil Palm Res. Vol. 26: 265-269.

Rodrigues-Neto, J C; Correia, M V; Souto, A L; Ribeiro, J A D A; Vieira, L R; Souza, M T; Rodrigues, C M and Abdelnur, P V (2018). Metabolic fingerprinting analysis of oil palm reveals a set of differentially expressed metabolites in fatal yellowing symptomatic and non-symptomatic plants. Metabolomics, 14(10): 142.

Roessner, U; Wagner, C; Kopka, J; Trethewey, R N and Willmitzer, L (2000). Simultaneous analysis of metabolites in potato tuber by gas chromatographymass spectrometry. Plant J., 23(1): 131-142.

Rongai, D; Sabatini, N; Del Coco, L; Perri, E; Del Re, P; Simone, N; Marchegiani, D and Fanizzi, F P (2017). ${ }^{1} \mathrm{H}$ NMR and multivariate analysis for geographic characterization of commercial extra virgin olive oil: A possible correlation with climate data. Foods, 6(11): 96.

Rosenblum, E S; Viant, M R; Braid, B M; Moore, J D; Friedman, C S and Tjeerdema, R S (2005). Characterizing the metabolic actions of natural stresses in the California red abalone, Haliotis rufescens using ${ }^{1} \mathrm{HNMR}$ metabolomics. Metabolomics, 1(2): 199-209.

Roslan, A and Idris, A S (2012). Economic impact of Ganoderma incidence on Malaysian oil palm plantation - A case study in Johor. Oil Palm Industry Economic J., 12(1): 24-30.
Rozali, N L; Yarmo, M A; Idris, A S; Kushairi, A and Ramli, U S (2017). Metabolomics differentiation of oil palm (Elaeis guineensis Jacq.) spear leaf with contrasting susceptibility to Ganoderma boninense. Plant Omics, 10(2): 45-52.

Safiza, M; Anita, J; Manaf, M A A and Fazliza, M A (2015). Differentially expressed genes in G. boninense naturally-infected palms. Proc. of the PIPOC 2015 International Palm Oil Congress. MPOB, Bangi. p. 617621.

Salekdeh, G H and Komatsu, S (2007). Crop proteomics: Aim at sustainable agriculture of tomorrow. Proteomics, 7(16): 2976-2996.

Sales, C; Cervera, M I; Gil, R; Portolés, T; Pitarch, E and Beltran, J (2017). Quality classification of Spanish olive oils by untargeted gas chromatography coupled to hybrid quadrupole-time of flight mass spectrometry with atmospheric pressure chemical ionization and metabolomics-based statistical approach. Food Chem., 216: 365-373.

Sambanthamurthi, R; Sundram, K and Tan, Y A (2000). Chemistry and biochemistry of palm oil. Prog. Lipid Res., 39(6): 507-558.

Sato, S; Soga, T; Nishioka, T and Tomita, M (2004). Simultaneous determination of the main metabolites in rice leaves using capillary electrophoresis mass spectrometry and capillary electrophoresis diode array detection. Plant J., 40(1): 151-163.

Seng, T-Y; Ritter, E; Saad, S H M; Leao, L-J; Singh, R; Zaman, F Q; Tan, S-G; Alwee, S S R S and Rao, V (2016). QTLs for oil yield components in an elite oil palm (Elaeis guineensis) cross. Euphytica, 212(3): 399425.

Shen, Z; Li, P; Ni, R-J; Ritchie, M; Yang, C-P; Liu, G-F; Ma, W; Liu, G-J; Ma, L; Li, S-J and Wei, Z G (2009). Label-free quantitative proteomics analysis of etiolated maize seedling leaves during greening. Mol. Cell. Proteom., 8(11): 2443-2460.

Shulaev, V (2006). Metabolomics technology and bioinformatics. Brief Bioinform.,7(2): 128-139.

Singh, R;Zaki, N M; Ting, N C; Rosli, R; Tan, S G; Low, E T L; Ithnin, M and Cheah, S C (2008). Exploiting an oil palm EST database for the development of gene-derived SSR markers and their exploitation for assessment of genetic diversity. Biologia, 63(2): 227235.

Singh, R; Low, E T L; Ooi, L C L; Ong-Abdullah, M; Nookiah, R; Ting, N C; Marjuni, M; Chan, P L; Ithnin, M; Mohamad Arif A M; Nagappan, J; Chan, 
K L; Rosli, R; Halim, M A; Azizi, N; Budiman, M A; Lakey, N; Bacher, B; Van Brunt, A; Wang, C; Hogan, M; He, D; Macdonald, J D; Smith, S W; Ordway, J M; Martienssen, R A and Sambanthamurthi, R (2014). The oil palm Virescens gene controls fruit colour and encodes a R2R3-MYB. Nat. Commun., 5: 4106. DOI: 10.1038 / ncomms5106.

Singh, R; Ong-Abdullah, M; Low, E T L; Mohamad Arif, A M; Rosli, R; Nookiah, R; Ooi, L C L; Ooi, S E; Chan, K L; Halim, M A A; Azizi, $\mathrm{N}$; Nagappan, J; Bacher, B; Lakey, N; Smith, S W; He, D; Hogan, M; Budiman, M A; Lee, E K; DeSalle, R; Kudrna, D; Goicoechea, J L; Wing, R A; Wilson, R K; Fulton, R S; Ordway, J M; Martienssen, R A and Sambanthamurthi, R (2013a). Oil palm genome sequence reveals divergence of interfertile species in Old and New worlds. Nature, 500: 335-339.

Singh, R; Low, E T L; Ooi, C L L; Ong-Abdullah, M; Ting, N C; Nagappan, J; Nookiah, R; Mohd Din, A; Rosli, R; Mohamad Arif, A M; Chan, K L; Mohd Amin, H; Azizi, N; Lakey, N; Smith, S W; Budiman, M A; Hogan, M; Bacher, B; Van Brunt, A; Wang, C; Ordway, J M; Sambanthamurthi, R and Martienssen, R A (2013b). The oil palm SHELL gene controls oil yield and encodes a homologue of SEEDSTICK. Nature, 500: 340-344.

Singh, R; Nagappan, J; Tan, S-G; Panandam, J M and Cheah, S C (2007). Development of simple sequence repeat (SSR) markers for oil palm and their application in genetic mapping and fingerprinting of tissue culture clones. Asia Pac. J. Mol. Biol Biotech., 15(3): 121-131.

Singh, R; Low, E T L; Ooi, L C L; Ong-Abdullah, M; Ting, N C; Nookiah, R; Ithnin, M; Marjuni, M; Mustaffa, S; Yaakub, Z; Amiruddin, M D; Manaf, M A A; Chan, K L; Halim, M A A; Sanusi, N S N M; Lakey, N; Sachdeva, M; Bacher, B; Garner, P A; MacDonald, J D; Smith, S W; Wischmeyer, C; Budiman, M A; Beil, M; Stroff, C; Reed, J; Van Brunt, A; Berg, H; Ordway, J M and Sambanthamurthi, R (2020). Variation for heterodimerization and nuclear localization among known and novel oil palm SHELL alleles. New Phytol., 226(2): 426-440.

Siti Suriawati, B; Chan, K L; Chan, P L; Parveez, G K A and Rasid, O A (2019). Identification of genes preferentially expressed in mesocarp tissue of oil palm using in silico analysis of transcripts. J. Oil Palm Res. Vol. 31(4): 540-549.

Sun, Q; Xue, J; Lin, L; Liu, D; Wu, J; Jiang, J and Wang, Y (2018). Overexpression of soybean transcription factors GmDof4 and GmDof11 significantly increase the oleic acid content in seed of Brassica napus L. Agronomy, 8(10): 222. https: / / doi.org/10.3390/agronomy8100222

Susanto, A; Sudharto, P S and Purba, R Y (2005). Enhancing biological control of basal stem rot disease (Ganoderma boninense) in oil palm plantations. Mycopathologia, 159(1): 153-157.

Syahanim, S; Othman, A; Manaf, M A A; Idris, A S and Amiruddin, M D (2013). Identification of differentially expressed proteins in oil palm seedlings artificially infected with Ganoderma: A proteomics approach. J. Oil Palm Res. Vol. 25(3): 298304.

Syahanim, S; Othman, A; Dzulkafli, S B; Hassan, H; Idris, A S; Amiruddin, M D and Ramli, U S (2019). Quantitative proteomics analysis of oil palm root during early stages of Ganoderma inoculation. BMC Proc., 13(8): 10.

Syrenne, R D; Shi, W; Stewart, C N and Yuan, J S (2012). Omics platforms: Importance of twentyfirst century genome-enabled technologies in seed developmental research for improved seed quality and crop yield. Seed Development: OMICS Technologies toward Improvement of Seed Quality and Crop Yield. Springer, Dordrecht. p. 43-57.

Tafti, A P; LaRose, E; Badger, J C; Kleiman, R and Peissig, P (2017). Machine learning-as-a-service and its application to medical informatics. International Conference on Machine Learning and Data Mining in Pattern Recognition. Springer, Cham., USA. p. 206219.

Tahir, N; Abas, F; Ghulam Kadir, A P; Ishak, Z and Ramli, U S (2012). Characterization of apigenin and luteolin derivatives from oil palm (Elaeis guineensis Jacq.) leaf using LC-ESI-MS/MS. J. Agr. Food Chem., 60: 11201-11210.

Tahir, N I; Shaari, K; Abas, F; Ishak, Z; Ahmad Tarmizi, H; Amiruddin, M D; Parveez, G K A and Ramli, U S (2016). Metabolome analysis of oil palm clone P325 of different planting trials. J. Oil Palm Res. Vol. 28(4): 431-441.

Tan, H S; Liddell, S; Abdullah, M O; Wong, W C and Chin, C F (2016). Differential proteomic analysis of embryogenic lines in oil palm (Elaeis guineensis Jacq). J. Proteomics, 143: 334-345.

Tang, G; Xu, P; Ma, W; Wang, F; Liu, Z; Wan, S and Shan, L (2018). Seed-specific expression of AtLEC1 increased oil content and altered fatty acid composition in seeds of peanut (Arachis hypogaea L.). Front. Plant Sci., 9: 260. 
Tarmizi, A; Haizam, A; Razak, A; Arni, R; Hammid, A; Niefaizal, A and Kuntom, A (2019). Effect of anticloudingagenton thefateof3-monochloropropane-1, 2-diol esters and glycidyl esters in palm olein during repeated frying. Molecules, 24(12): 2332.

Teh, H F; Neoh, B K; Ithnin, N; Daim, L D J; Ooi, T E K and Appleton, D R (2017). Omics and strategic yield improvement in oil crops. J. Amer. Oil Chem. Soc., 94(10): 1225-1244.

Teh, H F; Neoh, B K; Wong, Y C; Kwong, Q B; Ooi, T E K; Ng, T L M; Tiong, S H; Low, J Y S; Danial, A D; Ersad, M A; Kulaveerasingam, H and Appleton, D R (2014). Hormones, polyamines, and cell wall metabolism during oil palm fruit mesocarp development and ripening. J. Agric. Food Chem., 62 (32): 8143-8152.

Teh, C K; Ong, A L; Kwong, Q B; Apparow, S; Chew, F T; Mayes, S; Mohamed, M; Appleton, D and Kulaveerasingam, H (2016). Genome-wide association study identifies three key loci for high mesocarp oil content in perennial crop oil palm. Sci. Rep., 6(1): 19075.

Teh, H F; Neoh, B K; Hong, M P L; Low, J Y S; Ng, T L M; Ithnin, N; Thang, Y M; Mohamed, M; Chew, F T and Yusof, H M (2013). Differential metabolite profiles during fruit development in high-yielding oil palm mesocarp. PLoS ONE, 8(4): e61344.

Tester, M and Langridge, P (2010). Breeding technologies to increase crop production in a changing world. Science, 327(5967): 818-822.

Thomson, M J (2014). High-throughput SNP genotyping to accelerate crop improvement. Plant Breed. Biotechnol., 2(3): 195-212.

Thongthawee, S; Tittinutchanon, P and Volkaert, H (2010). Microsatellites for parentage analysis in an oil palm breeding population. Thai J. Genet., 3(2): 172-181.

Ting, N C; Zaki, N M; Rosli, R; Low, E T L; Ithnin, M; Cheah, S C; Tan, S G and Singh, R (2010). SSR mining in oil palm EST database: Application in oil palm germplasm diversity studies. J. Genetics, 89(2): 135-145.

Tolstikov, V V; Lommen, A; Nakanishi, K; Tanaka, $\mathrm{N}$ and Fiehn, O (2003). Monolithic silica-based capillary reversed-phase liquid chromatography/ electrospray mass spectrometry for plant metabolomics. Anal. Chem., 75(23): 6737-6740.

Torres, G A; Sarria, G A; Varon, F; Coffey, M D; Elliott, M L and Martinez, G (2010). First report of bud rot caused by Phytophthora palmivora on African oil palm in Colombia. Plant Disease, 94(9): 1163-1163.

Tres, A; Ruiz-Samblás, C; Van Der Veer, G and Van Ruth, S M (2013). Geographical provenance of palm oil by fatty acid and volatile compound fingerprinting techniques. Food Chem., 137: 142-150.

Turner, P D and Gillbanks, R A (2003). Oil Palm Cultivation and Management. Incorporated Society of Planters. Kuala Lumpur, Malaysia. 672 pp.

Uawisetwathana, U and Karoonuthaisiri, N (2019). Metabolomics for rice quality and traceability: Feasibility and future aspects. Curr. Opin. Food Sci., 28: 58-66.

Van Wijk, K J (2001). Challenges and prospects of plant proteomics. Plant Physiol., 126(2): 501-508.

Vargas, L H; Ribeiro, J A; Sifuentes, D N; Júnior, M T; Rodrigues, C M and Abdelnur, P V (2014). An analytical platform based on untargeted metabolomics for leaves of oil palm. Pesquisa $e$ Inovação da, 70770. $112 \mathrm{pp}$.

Wang, F; Wang, C; Liu, P; Lei, C; Hao, W; Gao, Y; Liu, Y-G and Zhao, K (2016). Enhanced rice blast resistance by CRISPR/Cas9-targeted mutagenesis of the ERF transcription factor gene OsERF922. PLOS ONE, 11(4): e0154027.

Wang, Z Q; Xu, X Y; Gong, Q Q; Xie, C; Fan, W; Yang, J L; Lin, Q S and Zheng, S J (2014). Root proteome of rice studied by iTRAQ provides integrated insight into aluminum stress tolerance mechanisms in plants. J. Proteomics, 98: 189-205.

Wang, Y; Htwe, Y M; Li, J; Shi, P; Zhang, D; Zhao, $\mathrm{Z}$ and Ihase, L O (2019). Integrative omics analysis on phytohormones involved in oil palm seed germination. BMC Plant Biol., 19: 363.

Weckwerth, W (2003). Metabolomics in systems biology. Annu. Rev. Plant Biol., 54(1): 669-689.

Weckwerth, W (2008). Integration of metabolomics and proteomics in molecular plant physiologycoping with the complexity by data-dimensionality reduction. Physiol. Plantarum, 132(2): 176-189.

Weir, G M (1968). Leaf spot of the oil palm caused by Cercospora elaeidis, Stey. Aspects of atmospheric humidity and temperature. J. Nigerian Institute for Oil Palm Research, 5(17): 41-55.

Woittiez, L S; Van Wijk, M T; Slingerland, M; Van Noordwijk, M and Giller, K E (2017). Yield gaps 
in oil palm: A quantitative review of contributing factors. Eur. J. Agron., 83: 57-77.

Yu, J; Hu, S; Wang, J; Wong, G KS; Li, S; Liu, B; Deng, Y; Dai, L; Zhou, Y; Zhang, X and Cao, M (2002). A draft sequence of the rice genome (Oryza sativa $\mathrm{L}$. ssp. indica). Science, 296(5565): 79-92.

Zhang, Y; Zhao, J; Xiang, Y; Bian, X; Zuo, Q; Shen, Q; Gai, J and Xing, H (2011). Proteomics study of changes in soybean lines resistant and sensitive to Phytophthora sojae. Proteome Sci., 9(1): 52.

Zhao, X X; Tang, Tan, G; Liu, F X; Lu, C L; Hu, $X$ L; Ji, LL and Liu, Q Q (2013). Unintended changes in genetically modified rice expressing the lysine-rich fusion protein gene revealed by a proteomics approach. J. Integr. Agric., 12(11): 2013-2021.

Zolla, L; Rinalducci, S; Antonioli, P and Righetti, P G (2008). Proteomics as a complementary tool for identifying unintended side effects occurring in transgenic maize seeds as a result of genetic modifications. J. Proteome Res., 7(5): 1850-1861.

Zulkifli, Y; Maizura, I and Rajinder, S (2012). Evaluation of MPOB oil palm germplasm (Elaeis guineensis) populations using EST-SSR. J. Oil Palm Res. Vol. 24: 1368-1377. 